\title{
Distribution of coral-microbialite reefs along the French Jura platform during the Bimammatum Zone (Oxfordian, Late Jurassic)
}

\author{
Nicolas Olivier
}

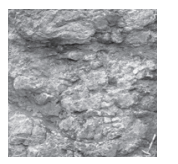

\begin{abstract}
During the Late Jurassic, the Jura platform was the site of major carbonate production involving various reef building components, particularly corals and microbialites. The existence of a detailed stratigraphic framework for the French Jura sedimentary succession during the Late Oxfordian-Early Kimmeridgian interval makes it possible to analyse the nature and distribution of these reefs within a high-resolution time frame, the Bimammatum Zone. Even though these reefs developed in a wide range of settings, their development was never optimal, indicating the presence of limiting factors. When the supply of terrigenous material was lower, the inner platform was characterized by strong carbonate production, with the development of a large ooidal shoal complex including ten-meter scale coral-microbialite patch reefs. The large size and high-density skeletal structure of some colonies indicates a favourable environment for coral and reef development (shallow, agitated, well-oxygenated waters with high light levels), despite the coral assemblage being poorly diversified and characterized by a mixed photo-heterotrophic association. The autocyclic character of the sedimentary system (i.e. major migrations of the ooidal dunes after big storm events) recurrently interrupted reef development. When the French Jura platform was subject to significant terrigenous input, the coral assemblages became well-diversified and characterized by mixed or heterotrophic-dominated associations. In the shallow and proximal areas of the inner ramp, limited available space imposed strong constraints on the reef growth, which only developed biostromal morphologies. Along the mid ramp, the reefs were composed firstly of plurimetric bioherms, then metric patches and finally coral meadows, highlighting the inversely proportional relationship of reef size to water depth. Once a certain depth was reached on the mid ramp, the presence of corals with heterotrophic feeding patterns could explain their reduced capacity to grow and build up a reef framework. Periods of greater terrigenous input, causing high turbidity and eutrophic conditions, led to frequent interruptions in reef growth both in the inner and more proximal mid ramp positions. This terrigenous influence is less pronounced in the central part of the mid ramp, where storms could alternatively stop reef development by causing migration of oncoidal sediments that then covered the small coral patches. In the distal part of the mid ramp, reef growth was reduced and relatively stable. Here, periods of reef development were controlled by long-term allocyclic processes that triggered the migration of oncoidal facial belts resulting from variations in relative sea level. - Key words: reefs, corals, microbialites, carbonate platforms, palaeoenvironments, Late Jurassic.
\end{abstract}

OLIVIER, N. 2019. Distribution of coral-microbialite reefs along the French Jura platform during the Bimammatum Zone (Oxfordian, Late Jurassic). Bulletin of Geosciences 94(3), 257-277 (13 figures, 1 table). Czech Geological Survey, Prague. ISSN 1214-1119. Manuscript received February 6, 2019; accepted in revised form July 18, 2019; published online September 30, 2019; issued November 30, 2019.

Nicolas Olivier, Université Clermont Auvergne, CNRS, IRD, Laboratoire Magmas et Volcans, F-63000 ClermontFerrand,France; nicolas.olivier@uca.fr

In the Late Jurassic, carbonate platforms and reefs were widespread in the various known geographical realms, north Tethysian, south Tethysian, north Atlantic, and Pacific (Leinfelder 2001). The many studies conducted by R. Leinfelder's German team during the 1990s have shown that these reefs were diversified and occupied specific ecological niches: stromatolites near the shore line, coral reefs in relatively shallow and proximal zones, siliceous sponge bioherms in deeper and distal parts of the platform, and microbial mounds in deep epicontinental basins (Leinfelder 1993, 2001; Leinfelder et al. 1993,
1996; Werner et al. 1994; Nose 1995; Schmid 1996; Nose \& Leinfelder 1997; Leinfelder \& Schmid 2000). These works paved the way for numerous publications about the coral assemblages, microbialites and microencrusters that were involved in the formation of these Late Jurassic reefs (Insalaco 1996; Insalaco et al. 1997; Bertling \& Insalaco 1998; Dupraz \& Strasser 1999, 2002; Olivier et al. 2003, 2004a, b, 2006; Mancini et al. 2004; Shiraishi \& Kano 2004; Reolid et al. 2005, 2009; Helm \& Schülke 2006; Matyszkiewicz et al. 2006, 2012; Pleş et al. 2013; Ricci et al. 2018a). Several studies on Late 
Jurassic reefs include detailed ecological studies such as coral zonations (Lathuilière et al. 2005, Rusciadelli et al. 2011, Martin-Garin et al. 2012, Ricci et al. 2018b), community replacements (Werner et al. 1994, Insalaco 1996, Pawellek \& Aigner 2003, Matyszkiewicz et al. 2006, Beresi et al. 2017, San Miguel et al. 2017), or putative ecological successions (Bill et al. 2011, Olivier et al. 2012). Moreover, Late Jurassic coral reefs also appear to have been affected by global climate change on a scale of a few million years, recording phases of latitudinal migrations (Cecca et al. 2005, Martin-Garin et al. 2012). All these studies point to the strong potential of Late Jurassic coral reefs in terms of palaeoecological and palaeoenvironmental reconstructions. Their spatial and temporal analysis nevertheless requires a well constrained stratigraphic framework, but good zone fossils generally remain rare in the rock record of Late Jurassic shallow epicontinental carbonate platforms. Upper Jurassic sedimentary successions of the Swiss and French Jura Mountains were thus studied on the basis of detailed sequencestratigraphy frameworks (Pittet \& Strasser 1998, Colombié \& Strasser 2005, Strasser 2007). Based on a framework of hierarchically stacked depositional sequences, some studies illustrated the distribution of certain Late Jurassic reefs on the scale of a carbonate platform (Aurell \& Bádenas 2004, Carpentier et al. 2006, Bádenas \& Aurell 2010, Olóriz et al. 2012). However, detailed studies of reef composition and distribution along a carbonated platform at a relatively high point in the time scale (i.e. an ammonite zone) remain rare (Dupraz 1999, Dupraz \& Strasser 2002). Thus, our knowledge of Late Jurassic coral reefs in a high-resolution time frame is still limited and new studies would provide a better understanding of the environmental parameters that have controlled their development and distribution.

During the Late Jurassic, the French Jura platform was the site of intense reef development, with coral reefs in proximal settings and sponge bioherms in more distal areas (Gaillard 1983, Bernier 1984). While the stratigraphic framework is relatively well constrained for sponge bioherms (Enay 1966, Gaillard 1983), the nature and the distribution of the coral reefs along the French Jura platform are only partially known (Beauvais \& Bernier 1981, Bernier 1984, Fookes 1995, Habrant \& Lathuilière 2000, Lathuilière et al. 2005, Olivier et al. 2011). Recent sedimentological work increased our knowledge of the French Jura platform during the Oxfordian-Kimmeridgian interval (Cariou 2013, Olivier et al. 2015). This highresolution sequence-stratigraphy framework makes it possible to analyse the composition and distribution of the coral reefs along this platform during a short time interval, the Bimammatum Zone. The aims of this study are (i) to provide a detailed analysis of the different coral reef structures studied in the French Jura, (ii) to illustrate their distribution along this ancient platform, and (iii) to discuss the main environmental parameters that controlled their composition and development.

\section{Geological context}

The reefs analysed in this study come from four localities (Mont Rivel, Loulle, Morillon and Molinges) in the French Jura Mountains (Fig. 1). These localities are in the department of the Jura and are aligned along a north-south axis between the towns of Nantua and Besançon. During the Late Jurassic, there were three paleogeographical sectors (northern, central and southern parts) along the French Jura platform (Enay et al. 1988, Cochet 1995, Cariou 2013, Olivier et al. 2015). Mont Rivel (46 $45^{\prime}$ $\left.36.91^{\prime \prime} \mathrm{N}, 5^{\circ} 55^{\prime} 7.26^{\prime \prime} \mathrm{E}\right)$, Loulle $\left(46^{\circ} 43^{\prime} 0.41^{\prime \prime} \mathrm{N}\right.$, $\left.5^{\circ} 53^{\prime} 32.65^{\prime \prime} \mathrm{E}\right)$ and Morillon $\left(46^{\circ} 37^{\prime} 56.48^{\prime \prime} \mathrm{N}, 5^{\circ} 56^{\prime}\right.$ $50.54^{\prime \prime}$ E) localities belong to the Central Jura, and Molinges ( $\left.46^{\circ} 21^{\prime} 6.24^{\prime \prime} \mathrm{N}, 5^{\circ} 45^{\prime} 59.46^{\prime \prime} \mathrm{E}\right)$ to the Southern Jura. Detailed information concerning stratigraphical and sedimentological contexts of these different reef localities can be found in the works of Olivier et al. (2011), Cariou (2013), Cariou et al. (2014), and Olivier et al. (2015). These studies have notably established highresolution biostratigraphical and sequential frameworks to accurately position the coral reefs sampled along the French Jura platform. Indeed, Upper Jurassic sedimentary successions of the French Jura Mountains display a clear hierarchical stacking pattern with notably well-marked medium-scale depositional sequences, which are linked to the 400-kyr eccentricity cycles (Olivier et al. 2011, Cariou et al. 2014). According to the sequential framework of Hardenbol et al. (1998), all the reefs of this study are thus included into the medium-scale sequences Ox6+ and Ox7 (Ox6+ is an additional medium-scale sequence initially identified by Hug 2003). These reefs are dated to the Late Oxfordian, and more precisely to the Bimammatum Zone (Tab. 1; Olivier et al. 2015).

Reefs of the Central Jura (i.e. Mont Rivel, Loulle and Morillon) are part of the Couches du Morillon Formation. Reefs of the Mont Rivel belong to the Oolithe du Mont Rivel Member, whereas reefs of the Loulle and Morillon are part of the Calcaires marneux récifaux de Loulle. Reefs of the Southern Jura (i.e. Molinges) belong to the Calcaires lités Formation. In the Oxfordian, the Jura was situated in a shallow epicontinental sea, between the Paris Basin to the north and the Delphino-helvetic Basin to the south (Thierry et al. 2000). During the Bimammatum Zone, the Mont Rivel, Loulle and Morillon reefs developed in shallow and relatively high-energy shoal setting (Couches du Morillon Formation), at the south of more inner-platform marls of the Marnes de Besançon Formation (Fig. 1; Gaillard 1983, Bernier 1984, Enay et 


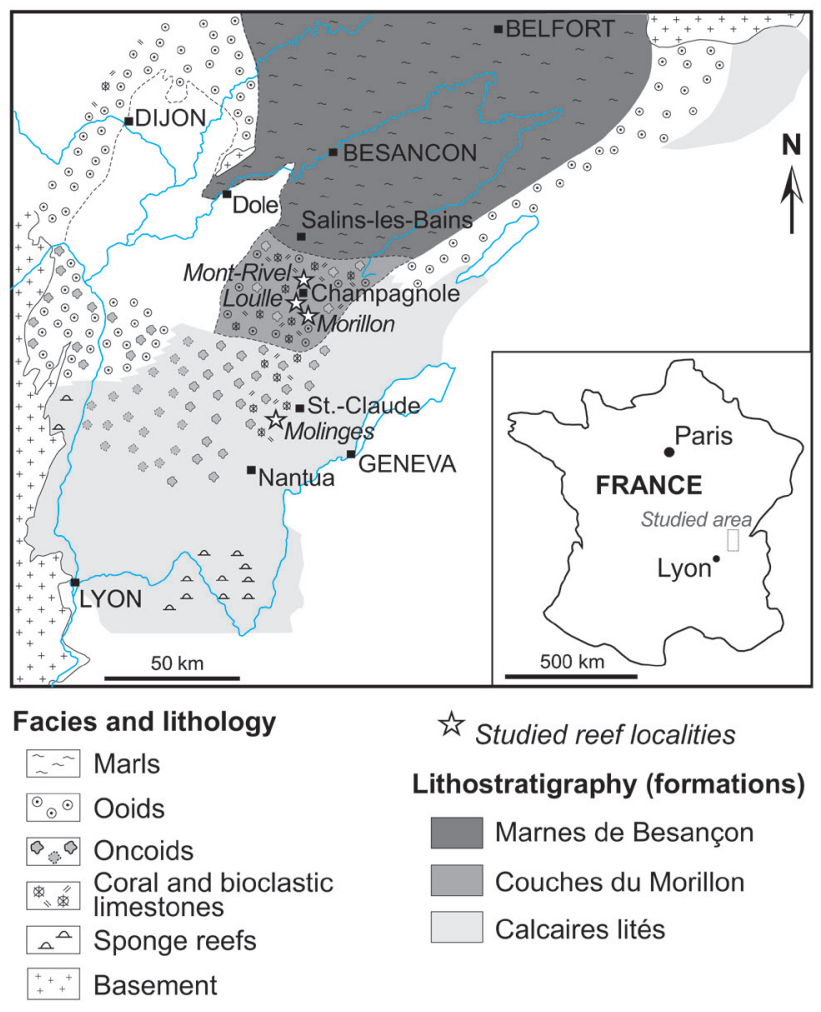

Figure 1. Geographic map showing the location of studied reefs and the extent of the Upper Oxfordian (Bimammatum Zone) lithostratigrapic formations and main facies in the French Jura (after Enay et al. 1988 and Olivier et al. 2015, modified).

al. 1988, Olivier et al. 2015). Further south, the Molinges reefs developed in a mid-shelf setting with oncoidal limestones (Troisième niveau à concretions Member) of the Calcaires lités Formation (Tab. 1). In its outermost part, the Southern Jura reveals sponge-microbialite bioherms that developed laterally to deep shelf marllimestone alternations (Gaillard 1983, Olivier 2004).

\section{Materials and methods}

This study is based on a detailed analysis of coral reefs and their relationship with lateral sediments. Information obtained from sediments situated laterally to the reefs, and their interpretations in terms of depositional settings, are found in Cariou (2013), Cariou et al. (2014) and Olivier et al. $(2011,2015)$. The data on the Molinges reefs come from the study of Olivier et al. (2011). Fieldwork was carried out for the Mont Rivel, Loulle and Morillon localities, to provide the reef dimensions, morphologies and their relationship with lateral deposits. The analysis of polished slabs by a point counting method on randomly selected surfaces, using a $20 \times 20 \mathrm{~cm}$ grid with a mesh of $1 \mathrm{~cm}^{2}$, enabled López (2011), Cariou (2013) and Olivier et al. (2011) to determine the relative abundance of the main reef components for the Loulle, Mont Rivel and Molinges localities. Due to poor outcrop conditions, this approach was not feasible for the Morillon reefs. The determination of corals was carried out on macroscopic samples (transversal and longitudinal sections in polished slabs) with the help of a binocular magnifying glass. Corals (460 specimens) have been identified for the localities of Mont Rivel, Loulle and Morillon. The determination of the Molinges corals is taken from Olivier et al. (2011). The corals were determined at a generic level, which is currently the most reliable taxonomic rank for the Jurassic (Lathuilière et al. 2005; Martin-Garin et al. 2010, 2012; Olivier et al. 2011, 2012; Ricci et al. 2018b).

\section{Reefs and coral assemblages}

\section{Mont Rivel}

The sedimentary succession of Mount Rivel reveals a stratigraphic unit about $12 \mathrm{~m}$ thick, which is rich in reef building and coral accumulations (López 2011, Cariou 2013, Olivier et al. 2015). Corals contributed to the building of numerous patch reefs up to 2 to 3 metres in thickness, with a lateral extension up to 15 metres (Fig. 2A, B). These patch reefs are embedded in a sedimentary unit of ooidal grainstones, which is part of the mediumscale depositional sequence Ox6+ (Olivier et al. 2015). Reef growth initiated on well-marked surfaces at the top of some ooidal beds. The reef tops also correspond to wellmarked surfaces that mark the base of prograding ooidal dunes (Fig. 2A). The framework of these patch reefs is mainly composed of corals ( $54 \%$ of the reef surface), associated with microbialites (thrombolites and leiolites; $22 \%$ ), various encrusting organisms (serpulids and oysters, $2 \%$ ), and lithophage bivalves (6\%; Cariou, 2013). The sediment cover represents $16 \%$ of the reef surface (Cariou 2013). Concerning the coral assemblage of these patch reefs, 7 genera are identified (Fig. 3A). The more abundant genera are Isastrea (33\% of the coral assemblage) and Thamnasteria (26\%). The other main genera are Microsolena (14\%), Dermosmilia (9\%), Stylosmilia (9\%) and Stylina $(7 \%)$. The coral framework is dominated by massive colonies, which can exceed $50 \mathrm{~cm}$ in diameter, associated with $\mathrm{dm}$-scale ramose and phaceloid colonies.

In addition to these patch reefs, the Mont Rivel sedimentary succession reveals small channels and rubble accumulations which are rich in corals (López 2011, Cariou 2013, Olivier et al. 2015; Fig. 2C). The channels are $\mathrm{dm}$-thick with a lateral extension of 5 to 10 metres. They have erosive bases locally and oblique stratification, indicating lateral accretion (López 2011). The coral assemblage in these channels is composed of 10 genera, and these reworked colonies mainly belong to the genera 

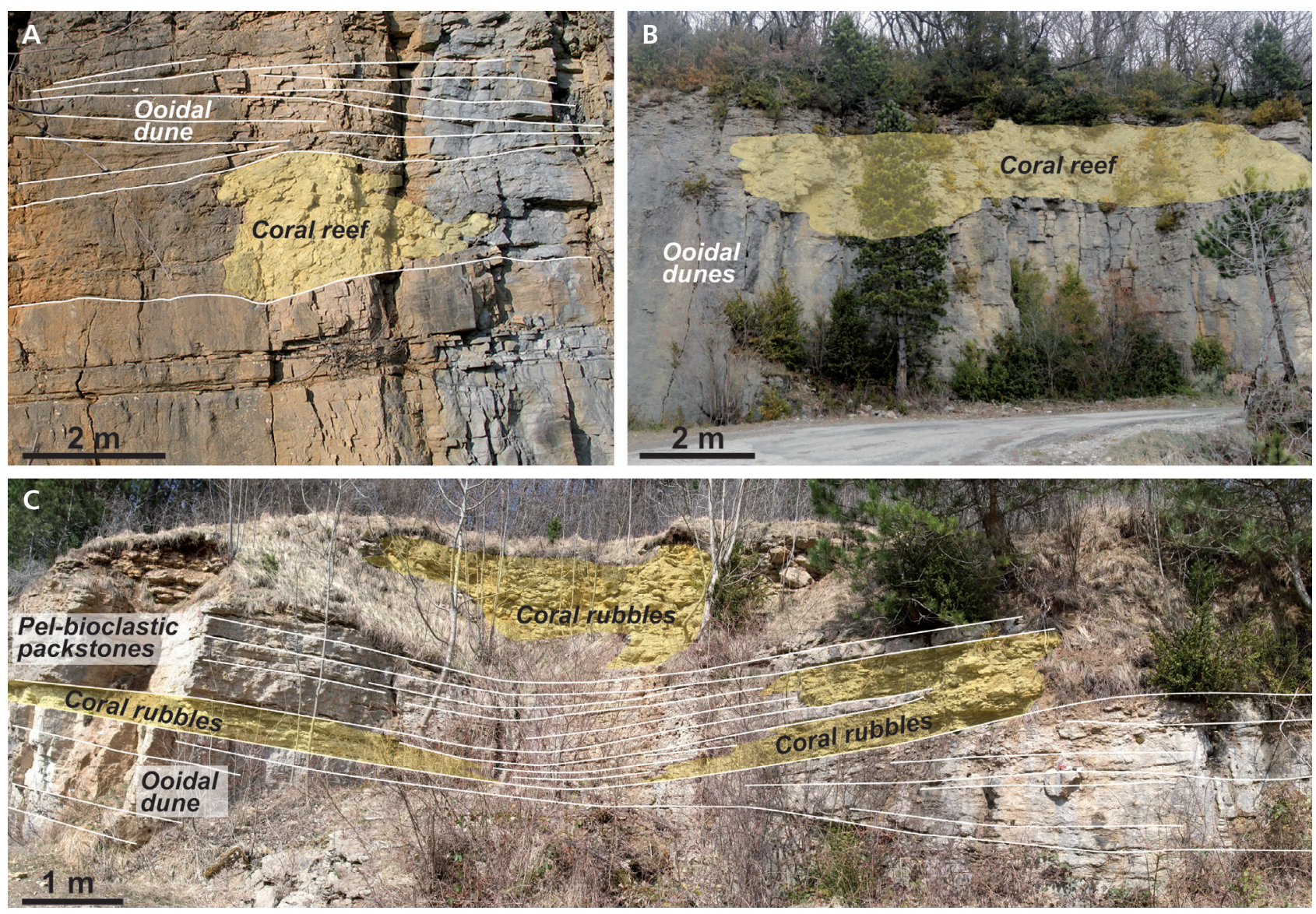

Figure 2. Field views of coral reefs and accumulations observed at Mont Rivel; A, B - metric to pluri-decametric patch reefs in ooidal dunes; $\mathrm{C}-\mathrm{dm}$ - to pluri-metric thick coral accumulations in pel-bioclastic limestones.

Thamnasteria $(60 \%)$, Comoseris (11\%), Stylina $(9 \%)$ and Dermosmilia (9\%; Fig. 3B). Even reworked, these corals display varied morphologies, ranging from small pluri-cm scale massive colonies, to thin lamellar colonies (Thamnasteria) of several decimetres in diameter, as well as large branching colonies of Dermosimilia (exceeding $1 \mathrm{~m}$ in height and $80 \mathrm{~cm}$ in diameter). Coral rubble accumulations are thicker (up to $8 \mathrm{~m}$ ) and seem to have a limited lateral extension, passing into peloidal and bioclastic packstones (Fig. 2C). These packstones are notably made of fragments of echinoderms, bivalves, corals, as well as some oncoids (Olivier et al. 2015). The actual reef framework and corals preserved in life position was not observed, suggesting a floatstone to rudstone texture with reworked colonies, which is consistent with erosive surfaces observed at the base of some of these rubble accumulations. Coral colonies display common boring bivalves and encrusting oysters, but are devoid of microbialitic crusts. This coral rubble interval is moderately diversified with a coral assemblage made of only 11 genera (Fig. 3C). Thamnasteria (43\%) Enallhelia (17\%) and Dermosmilia (14\%) are the main genera. Colonies of Thamnasteria are frequently observed with a lamellar morphology with dimensions from 8 to
$10 \mathrm{~cm}$ in diameter and from 0.5 to $1.5 \mathrm{~cm}$ in thickness. Dendroid colonies of Enallhelia can reach more than $30 \mathrm{~cm}$ in diameter, and massive colonies commonly display diameters of 10 to $15 \mathrm{~cm}$.

\section{Loulle}

At Loulle, the stratigraphic interval containing the reefs is about $4 \mathrm{~m}$ thick and belongs to the medium-scale depositional sequence Ox7 (Olivier et al. 2015). Lateralreef sediments consist of limestone beds with marly intercalations (Cariou et al. 2014). Limestones are peloidal packstones (locally wackestones) with some sparse oncoids and ooids. These beds are well bioturbated and contain common fragments of crinoids and bivalves, associated with some corals, serpulids, benthic foraminifera and brachiopods. Sedimentary structures are rare, including small erosive surfaces and planar to low angle stratifications. The reef interval can be subdivided into 3 main reef growing phases. The first two growth phases have a biohermal morphology and do not exceed about ten metres in diameter (P1 and P2, Fig. 4A, B). 


\section{A Coral reefs}

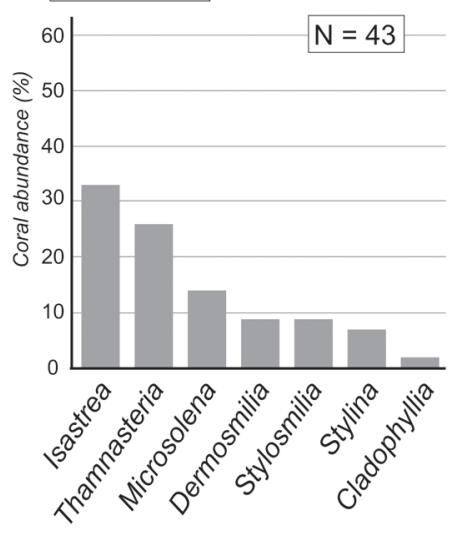

B Channel coral accumulations

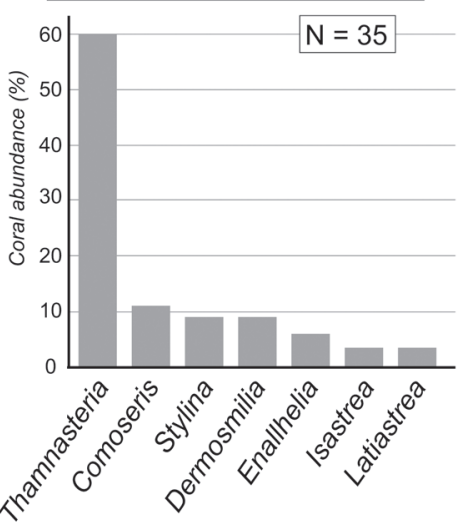

C Coral rubble accumulations

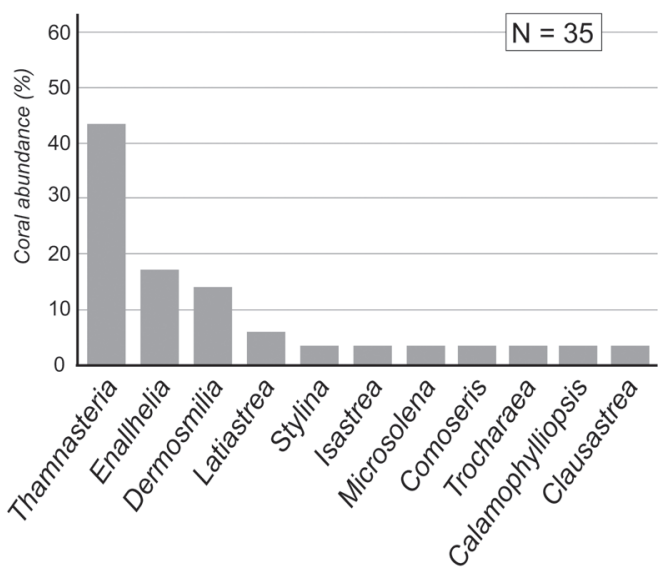

Figure 3. Abundances of coral genera (expressed in \%) identified in coral reefs and accumulations at Mont Rivel; A - coral patch reefs; B - channels rich in coral accumulations between ooidal dunes; $\mathrm{C}$ - coral rubble accumulations. Abbreviation: $\mathrm{N}$ - number of corals.
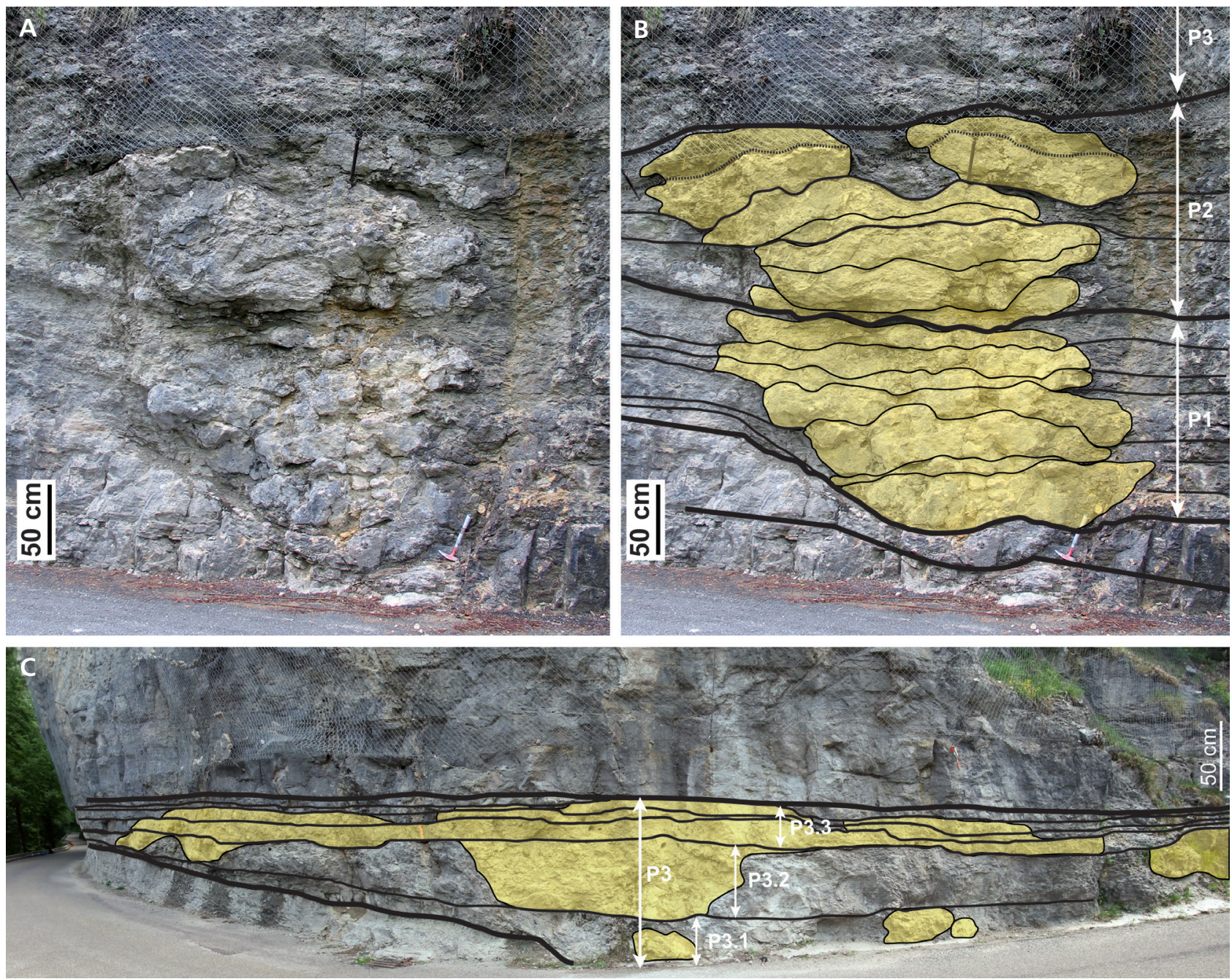

Figure 4. Field views of the coral reefs observed at Loulle, along the D253 road, about 15 meters below the stratigraphic interval that records dinosaur tracks (cf. Cariou et al 2014, Mazin et al 2016). • A, B - field view and interpretive photo of patch reefs observed in the lower part (i.e. reef growth phases P1 and P2) of the stratigraphic reef interval of Loulle. $\bullet \mathrm{C}$ - interpretive field view of the upper part (i.e. reef growth phase P3 and subphases P3.1 to 3.3) of the stratigraphic reef interval of Loulle. 


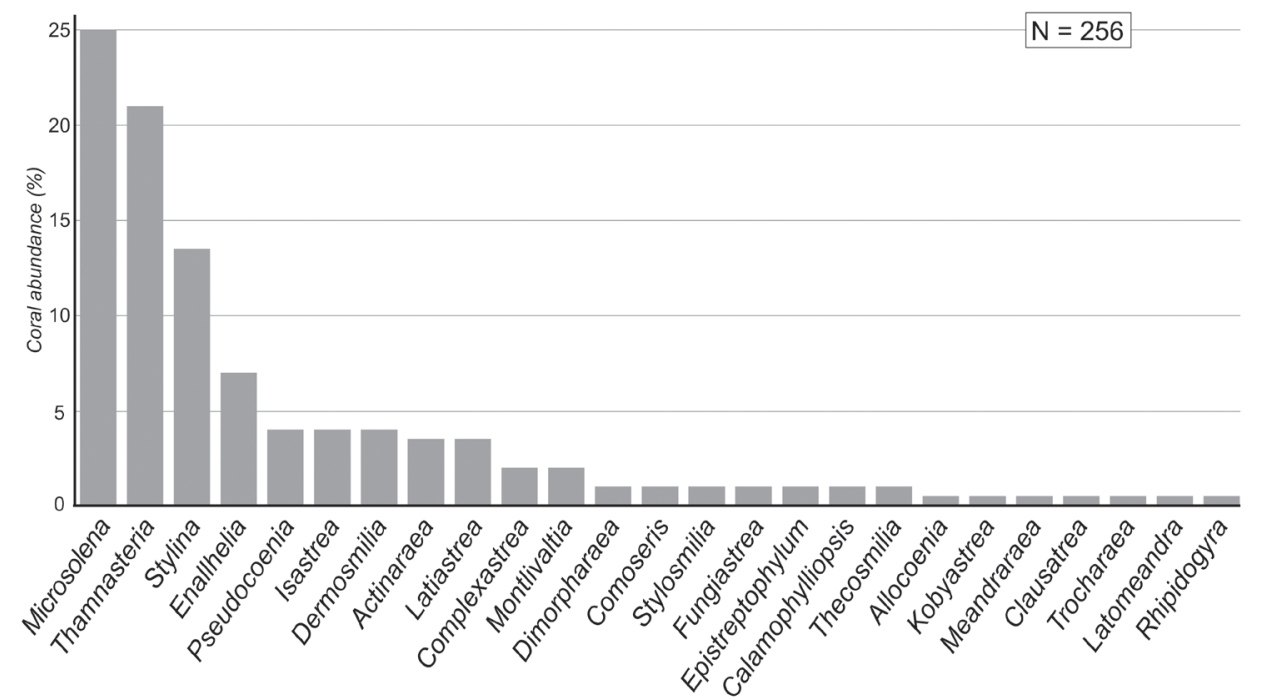

Figure 5. Abundances of coral genera (expressed in \%) identified in the entire reef interval (i.e. reef growth phases $\mathrm{P} 1$ to $\mathrm{P} 3$ ) at the Loulle locality. Abbreviation: $\mathrm{N}$ - number of corals. See Fig. 4 for field illustrations of the successive reef growth phases observed at Loulle. Detailed coral compositions of the different reef growth phases are given in Fig. 6.
The third and last growth phase can be subdivided into 3 subphases (P3.1 to P3.3, Fig. 4C). Growth phases 3.1 and 3.2 outcrop as small dm- to m-scale patches, whereas growth phase 3.3 displays a biostromal morphology with a lateral extension of about 10 metres. The upper part of reef growth phase 3, as well as lateral beds, appear truncated (Cariou et al. 2014). Reef growth phases 1 and 2 are mainly made of corals (58\% of the reef surface) and microbialites (thrombolites and leiolites; 30\%; Cariou 2013). Sediments, lithophage bivalves and epifauna (oysters and serpulids) constitute respectively 10\%, 3\% and $1 \%$ of the reef surface (Cariou 2013). As a whole, the reef surface of the third growth phase shows a relatively similar proportion of corals (41\%) and sediments (44\%). Microbialites (thrombolites and leiolites) and sessile epifauna (oysters and serpulids) represent $14 \%$ and $1 \%$ of the reef surface, respectively (Cariou 2013). No trace of bioerosion could be observed. In detail, subphase 3.1 displays relatively sparse corals (only $23 \%$ of the reef surface) and rare microbialites (4\%). Subphase 3.2 is mainly composed of corals ( $70 \%$ of the reef surface), with minor amounts of sediments and microbialites $(15 \%$ and $15 \%$, respectively). Subphase 3.3 appears relatively rich in microbialites ( $22 \%$ of the reef surface), whereas the corals do not exceed 29\% (Cariou 2013).

Concerning the coral assemblage, 25 genera have been identified throughout the entire Loulle reef interval (Fig. 5). A total of 17 genera were identified in reef growth phases 1 and 3, and 14 genera in phase 2 (Fig. 6). In detail, reef growth phase 3 is made of 7, 9 and 14 genera for subphase 3.1, 3.2 and 3.3, respectively. As a whole, the Loulle coral assemblage is dominated by 4 genera: Microsolena, Thamnasteria, Stylina and Enallhelia (Fig. 5). The remaining 21 genera each represent less than $5 \%$ of the coral assemblage. After Thamnasteria and Microsolena, the third most abundant genus for reef growth phases 2 and 3 is Stylina, and Enallhelia for the first phase (Fig. 6). Massive forms, such as colonies of Microsolena that reach $15 \mathrm{~cm}$ in diameter and $11 \mathrm{~cm}$ in thickness, mainly represent coral morphologies. Colonies of Thamnasteria display both massive (more than $15 \mathrm{~cm}$ in diameter and $9 \mathrm{~cm}$ in thickness) and lamellar morphologies ( $>11 \mathrm{~cm}$ in diameter and $2.5 \mathrm{~cm}$ in thickness). The dendroid genus Enallhelia can exceed $10 \mathrm{~cm}$ in diameter. Branching colonies of Dermosmilia can also exceed $40 \mathrm{~cm}$ in diameter. The third subphase seems to be distinguished by a lower proportion of Thamnasteria $(6 \%)$, and a further five genera (Enallhelia, Latiastrea, Stylina, Complexastrea and Montlivaltia) that constitute around $10 \%$ each of the coral assemblage.

\section{Morillon}

The reef interval observed at Morillon is about 10 to 15 metres thick and belongs to the medium-scale depositional sequence Ox7 (Olivier et al. 2015). Due to the vegetation, only the middle part of this reef interval is clearly visible along the N5 road (Fig. 7). Corals make up small decimetric to metric patches, which lie within a sedimentary succession made up of limestone beds and marly interbeds. Decimetre-thick limestone beds are oncoidal and bioclastic limestones with a packstone texture. These oncoidal beds are observed laterally and also stratigraphically intercalated between the coral patch reefs. Marly interbeds are correlated with surfaces of reef growth interruption. The small size and poor outcrop conditions made it impossible to estimate the proportion of the different reef components. Nevertheless, the reef framework mainly consists of corals and microbialites 
Figure 6. A-E - detailed abundances of coral genera (expressed in \%) identified in the different reef growth phases $(\mathrm{P} 1, \mathrm{P} 2)$ and subphases (P3.1-3.3) identified at Loulle. Abbreviation: $\mathrm{N}$ - number of corals. See Fig. 4 for a field illustration of the different phases and subphases of reef growth.

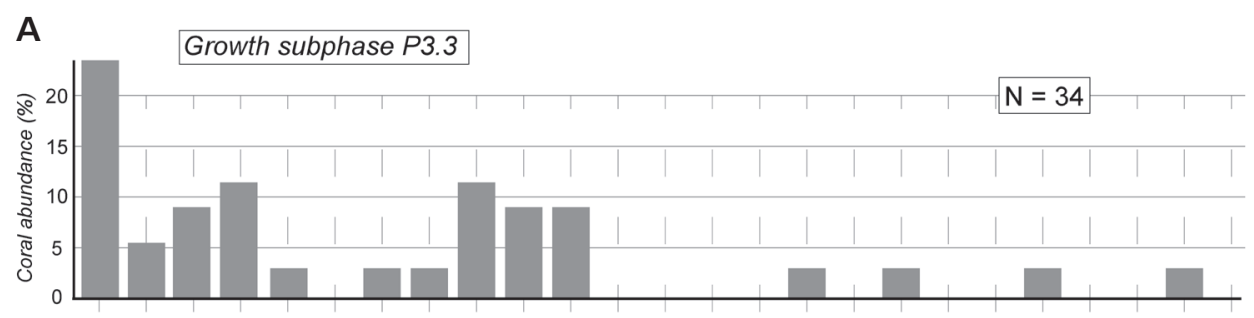

B

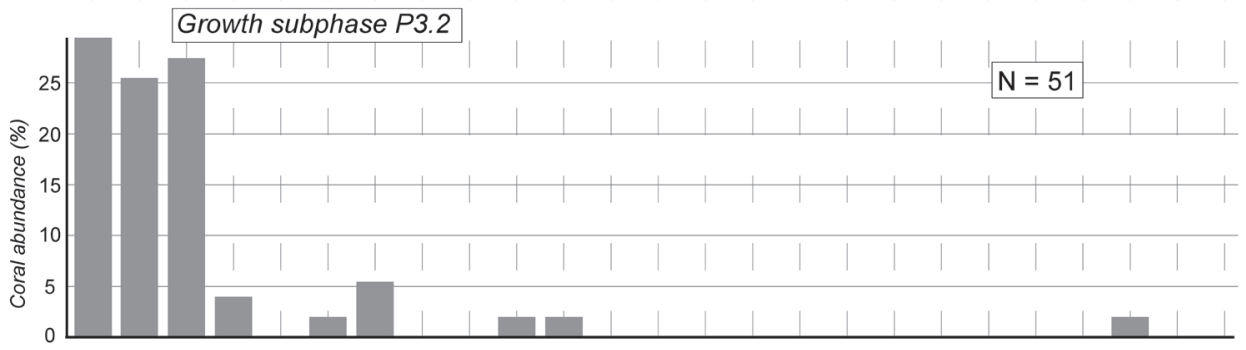

C

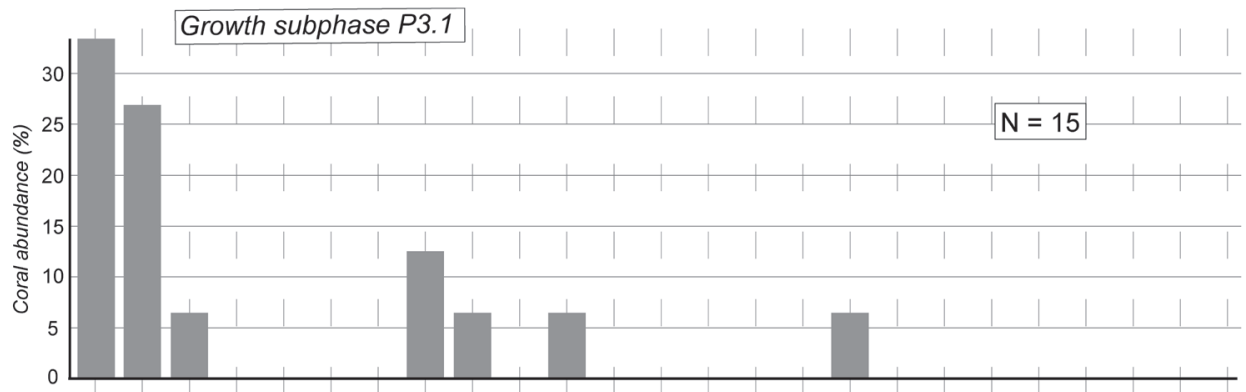

D

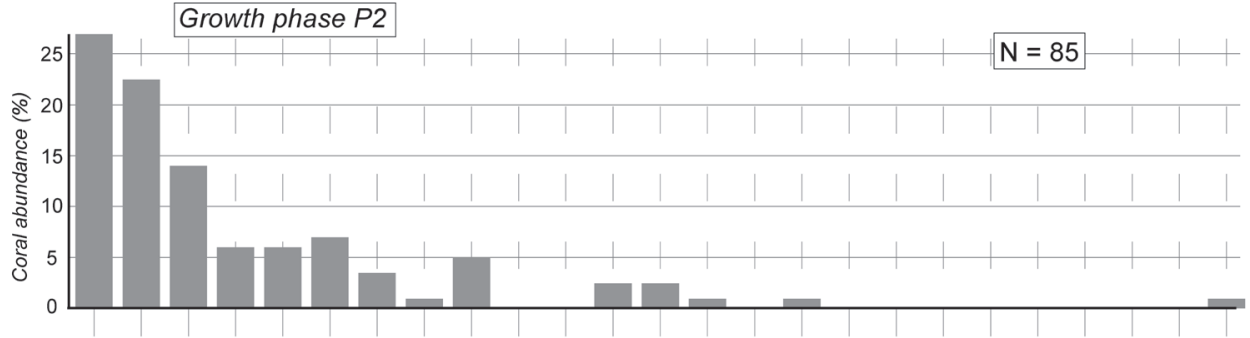

E

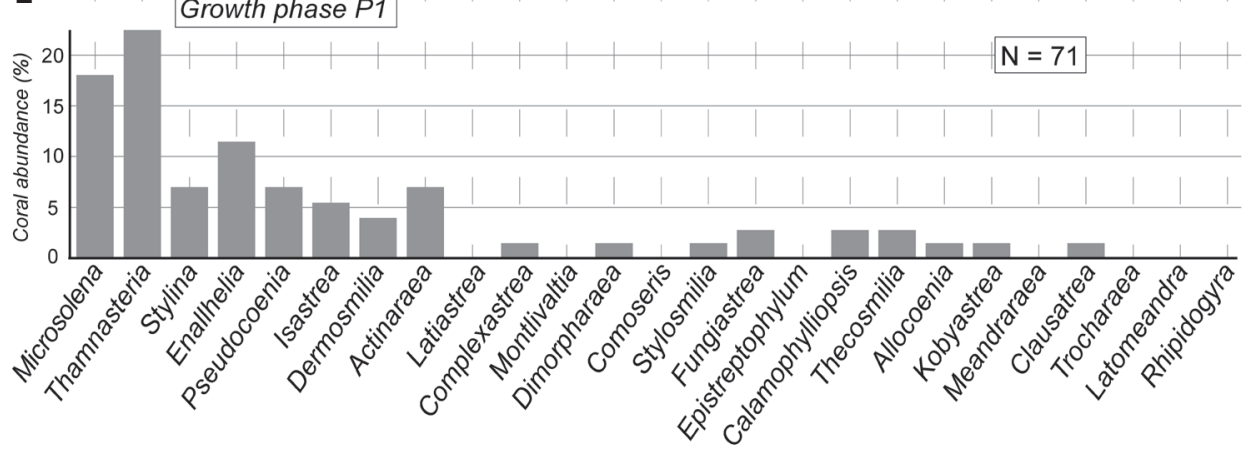




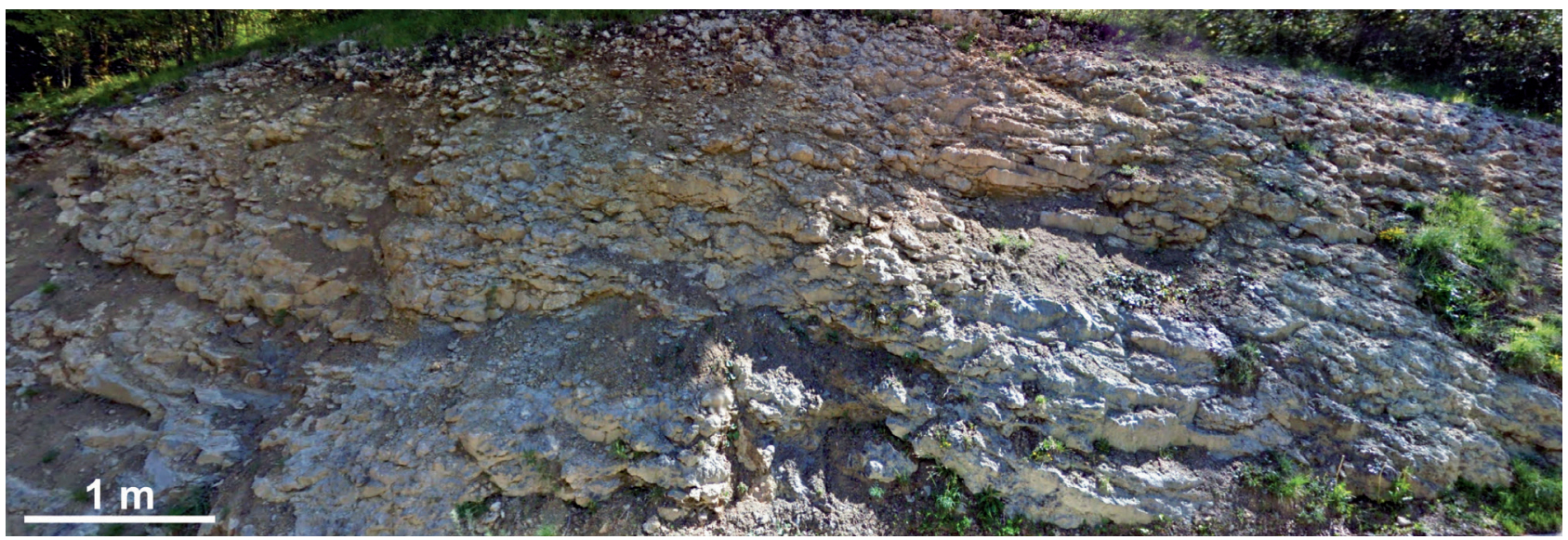

Figure 7. Field view of the studied stratigraphic reef interval at the Morillon locality, along the N5 road.

(thrombolites and leiolites) in proportions that appear to be comparable with those of the Loulle bioherms. Analysis of the coral samples reveals a relatively diversified assemblage with 18 identified genera (Fig. 8). Microsolena (24\%) and Thamnasteria $(18 \%)$ dominate the assemblage, followed by Enallhelia (12\%), Latomeandra (7.5\%), Thecosmilia $(7.5 \%)$ and Cladophyllia (5\%). Each of the remaining 12 genera constitutes less than $5 \%$ of the coral assemblage. Massive colonies of Microsolena can reach $20 \mathrm{~cm}$ in diameter and $12 \mathrm{~cm}$ in thickness. The Thamnasteria and Fungiastrea colonies do not exceed $11 \mathrm{~cm}$ in diameter and $4 \mathrm{~cm}$ in thickness. A phaceloid colony of the genus Latomeandra is $22 \mathrm{~cm}$ in diameter and $11 \mathrm{~cm}$ thick.

\section{Molinges}

At Molinges, a detailed description and analysis of the stratigraphic reef interval can be found in Olivier et al.
(2011). It is approximately $12 \mathrm{~m}$ thick, and is composed of 7 reef units (Molinges beds 1 to 7), which are intercalated with oncoidal limestone beds (Fig. 9). Six reef units (Molinges beds 1-2 and 4-7) correspond to dm- to m-scale beds that display a biostromal morphology. Only one reef unit (Molinges bed 3) has a biohermal morphology with small-size patches (up to $1.5 \mathrm{~m}$ wide by $0.9 \mathrm{~m}$ thick). On average, the framework and the sediment cover constitute respectively $76 \%$ and $24 \%$ of the reef surface of the four biostromal units (Molinges beds 1, 2, 4, 5), which developed during the sequence Ox6+ (Olivier et al. 2011). The framework of these four biostromal units is mainly made up of microbialites (37\% of the reef surface) and corals $(22 \%)$, and to a lesser extent by lithistid sponges (3\%; Olivier et al. 2011). Coral proportions vary highly between units and constitute between $9 \%$ and $33 \%$ of the reef surface. However, three of these four biostromal units have a coral surface area of between $28 \%$ and $33 \%$. The biostromal unit with the lowest coral cover (Molinges

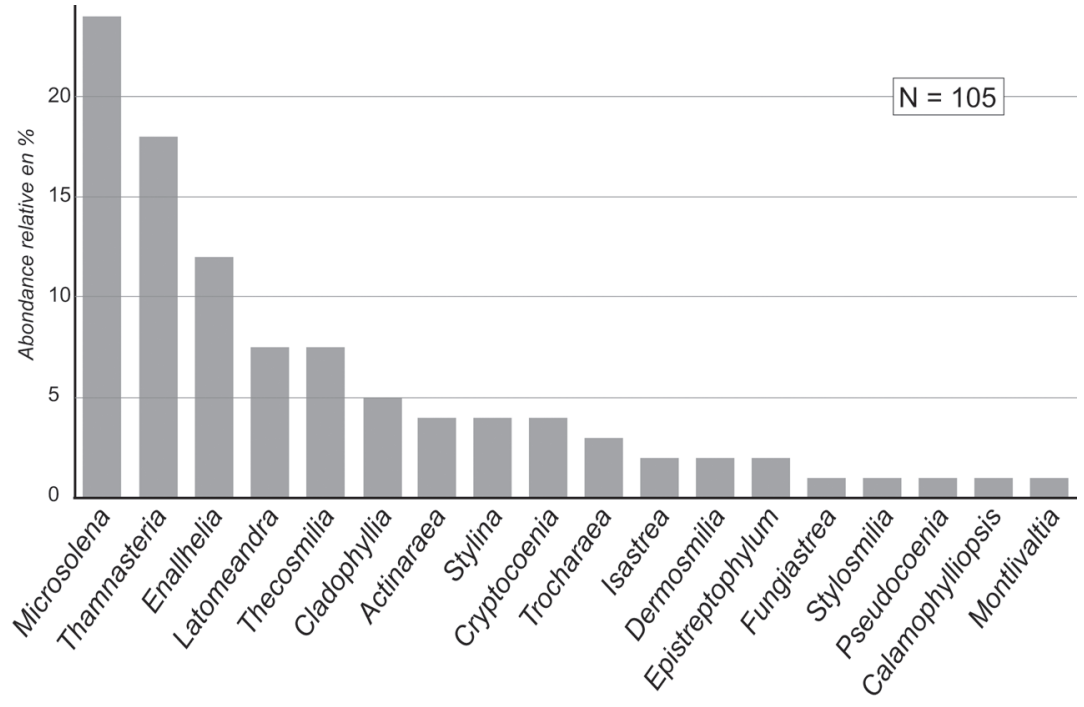

Figure 8. Abundance of coral genera (expressed in \%) identified in the studied reef interval at the Morillon locality. Abbreviation: $\mathrm{N}$ - number of corals. See Fig. 7 for a field illustration of this coral reef interval. 


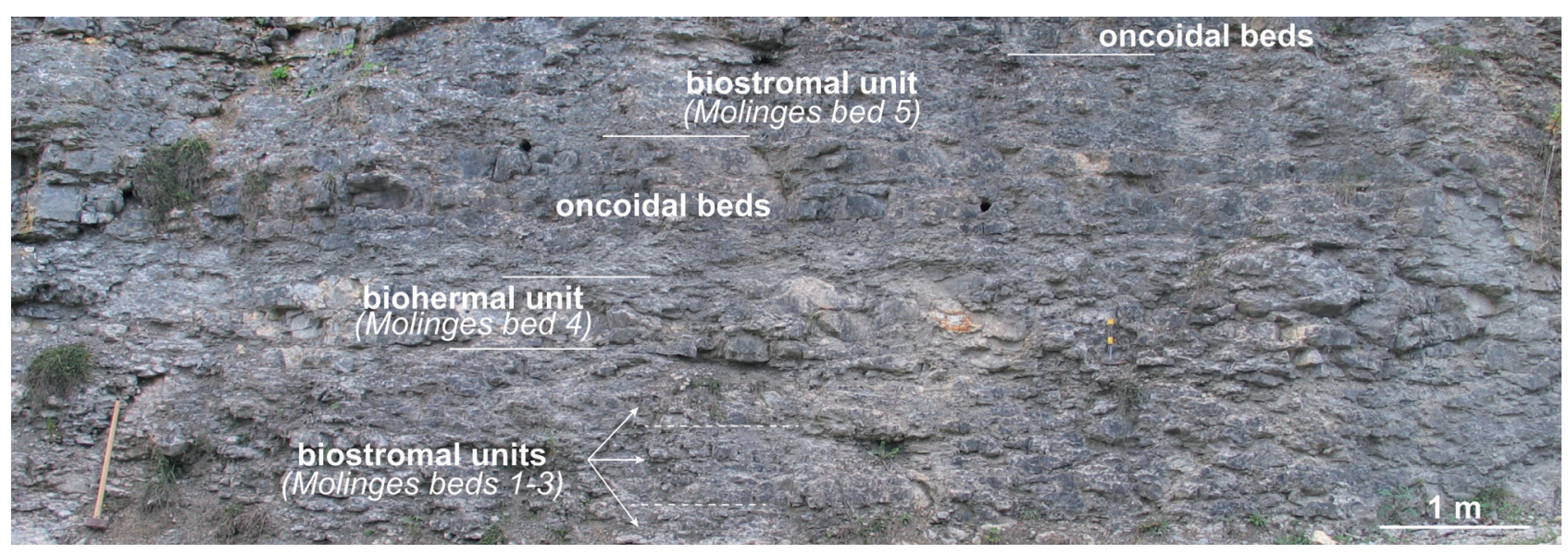

Figure 9. Field view of some coral reef units at the Molinges locality, along the D63 road (see Olivier et al. 2011).

bed $3 ; 9 \%$ ) is characterized by a higher proportion of sediments $(40 \%)$, as well as a higher presence of lithistid sponges $(6 \%)$ and encrusting microorganisms $(10 \%)$. Similarly, the reef surface occupied by microbialites varies significantly between these four biostromal units (between $34 \%$ and $42 \%$ ), but it is always higher than that of the coral surface. Concerning the two biostromal units that developed during the Ox7 sequence (Molinges beds 6 and 7), the framework and sediment cover vary only slightly and constitute on average $61 \%$ and $39 \%$ of the reef surface, respectively. The surface occupied by corals in the framework is generally relatively low $(16 \%)$ and smaller than that occupied by microbialites (26\%). One biostromal unit (Molinges bed 6) has a low proportion of microbialites ( $13 \%$ of the reef surface), which is counterbalanced by a relatively high proportion of microencrusting organisms (10\% of serpulids; Olivier et al. 2011).

Considered individually, the six biostromal units contain between 7 and 16 coral genera and do not show significant differences between the most frequent taxa (Olivier et al. 2011). Taken as a whole, the reefal interval is composed of 22 coral genera (Fig. 10). One of the specific features of the Molinges coral assemblage is its richness in dendroid colonies of the genus Enallhelia (30\% of the entire coral assemblage). Associated forms correspond to genera with a thamnasteroid structure such as Dimorpharaea and Thamnasteria (15 and 11\% of the coral assemblage, respectively). The assemblage also reveals a relatively high proportion of solitary corals such as Montlivaltia (10\% of the coral assemblage, but up to $31 \%$ in some reef units) or Epistreptophyllum. The different coral colonies are rather small in size and only a few solitary forms seem to be of larger dimensions (Olivier et al. 2011). Certain solitary Epistreptophyllum corals reach $5 \mathrm{~cm}$ in diameter, while the most common Enallhelia branching colonies do not exceed $10 \mathrm{~cm}$ in width. When lamellar, thamnasteroid forms (e.g. Thamnasteria or Dimorpharaea) do not exceed 10 to $15 \mathrm{~cm}$ in diameter and 1 to $2 \mathrm{~cm}$ in thickness. The Dimorpharaea colonies have more rounded and irregular morphologies, with the largest reaching $17 \mathrm{~cm}$ in diameter and $9 \mathrm{~cm}$ in thickness.

\section{Coral reef distribution}

Based on a high-resolution sequential analysis and the biostratigraphic framework initially carried out by Cariou (2013), and further developed in Olivier et al. (2015), the coral reef distribution along the French Jura platform can be analysed within a single ammonite zone of the Upper Oxfordian, the Bimammatum Zone. For this stratigraphic interval, two models of reef distribution can be distinguished, a first one during Ox6+ and a second one during the $\mathrm{Ox} 7$ sequences. While significant differences have been observed within these two different sedimentary systems (Olivier et al. 2015), the overall distribution between the main categories of reef formation remains unchanged along the platform with various coral reefs above the storm wave base level, and sponge bioherms at lower offshore settings (Gaillard 1983, Bernier 1984, Enay et al. 1988, Fookes 1995, Olivier 2004, Lathuilière et al. 2005, Olivier et al. 2011).

\section{Ox6+ model of coral reef distribution}

The first model of reef distribution took place during the sequence Ox6+ (Tab. 1). In this model, coral buildups are both observed in inner (Mont Rivel) and mid ramp (Molinges) settings (Fig. 11). The inner ramp area appears to have been relatively large with the development of an important ooidal shoal in which there are meter to pluri-m scale coral-microbialite patches (Olivier et al. 2015). These low-diversification coral reefs (only 7 genera) have a strong reef framework made of corals and microbialites 


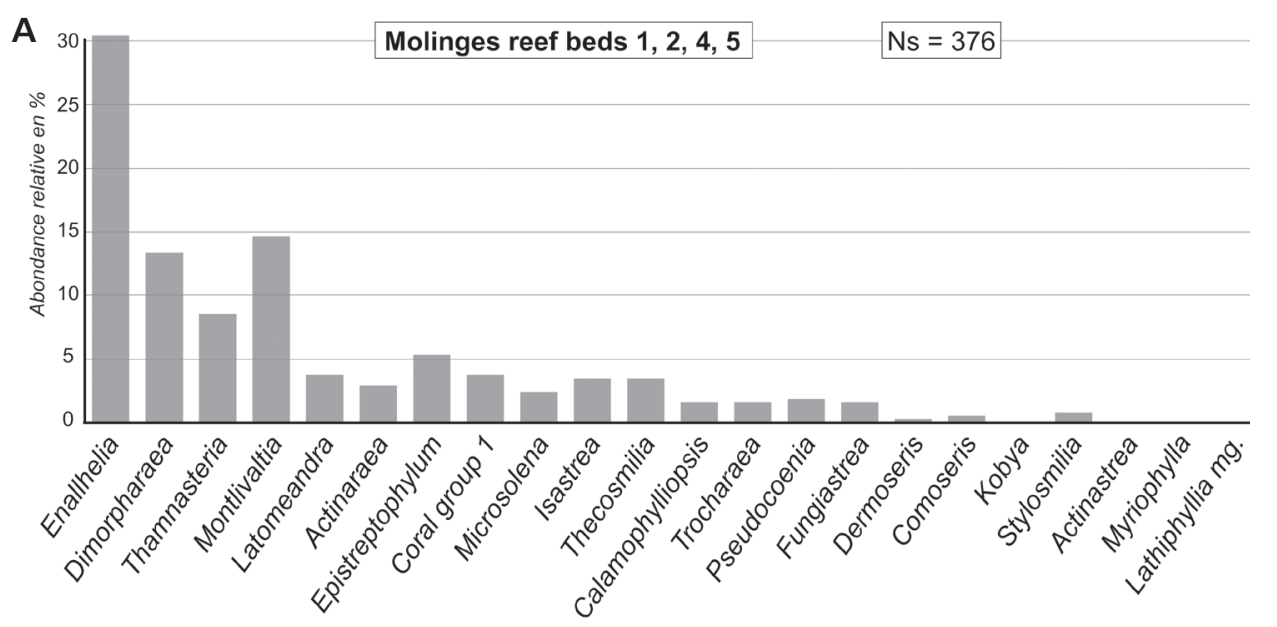

Figure 10. Abundances of coral genera (expressed in \%) identified in the different reef units at the Molinges locality (after Olivier et al. 2011, modified); A - biostromal units (Molinges beds 1, 2, 3, 5); $\mathrm{B}$ - biohermal bed (Molinges bed 3); C-biostromal units (Molinges beds 6 and 7). Abbreviation: $\mathrm{Ns}$ - number of specimens. See Fig. 9 for a field illustration of some of these coral reef units.
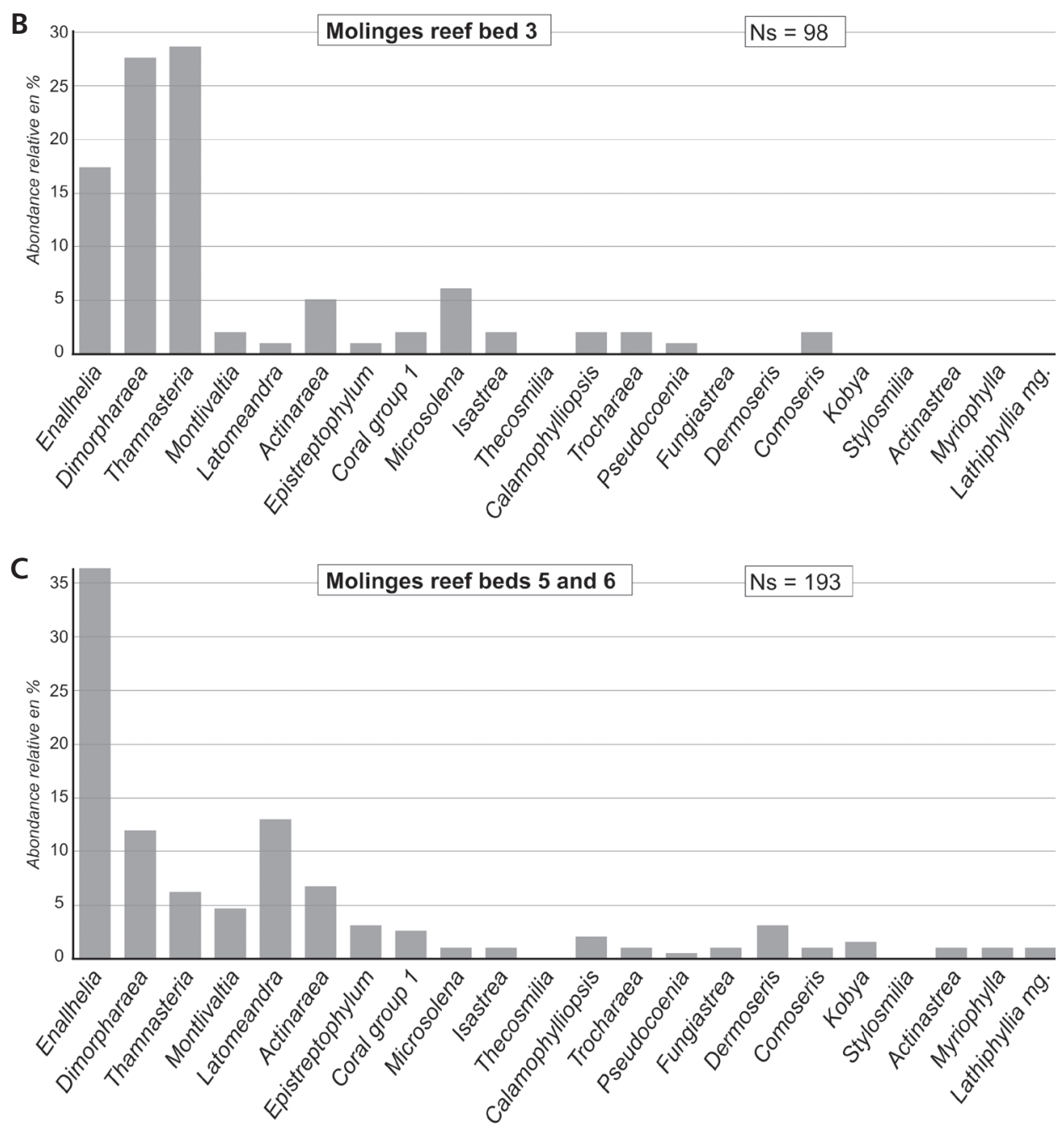

( $84 \%$ of the reef surface), with only a minor sedimentary cover $(16 \%)$. The coral framework is made up mostly of massive colonies of the genus Isastrea, associated with some large size branching forms of Dermosmilia. Interdune areas are filled by peloidal and bioclastic sedimentation where two types of coral accumulations can be identified. Accumulations of sparse reworked corals, comprising mainly lamellar (Thamnasteria) and branching (Enallhelia and Dermosmilia) colonies occur in small channels. A second type of accumulation is thicker units of 
coral rubble. These reworked corals probably reflect areas of preferential accumulation after major storm events, leeward of some reef constructions or ooidal dunes.

Probably due to a significant development of the ooidal shoal complex, the mid ramp zone is not very laterally extensive (Fig. 11). Large coral meadows developed in the external part of the mid ramp and some rare and small $\mathrm{dm}$-scale patches seem to have occurred slightly more proximally. Oncoidal marls characterize the most distal part of the mid ramp, while alternations of marllimestone occur on the outer ramp (Olivier et al. 2011). Mid ramp coral meadows led to the formation of several biostromal units, in which the sediment cover occupies near a quarter of the reef surface. Corals $(22 \%$ of the reef surface) largely contributed to the building of the reef framework, together with an important amount of microbialites (37\%). Coral diversity is relatively high, with 18 genera identified, and the coral assemblage is characterized by a high abundance of dendroid morphologies belonging to the genus Enallhelia (29\%). These gracile colonies never reach a large size (only few decimetres) and are mainly associated with some isolated corals (Montlivaltia) and some lamellar Dimorpharaea. Small $\mathrm{dm}$-scale coral bioherms have a dense framework $(85 \%$ of the reef surface) with a low sediment cover (15\%). Corals are the most common components $(33 \%$ of the reef surface) and are mainly represented by the lamellar
Thamnasteria (28\% of the coral assemblage) and Dimorpharaea $(27 \%)$, and to a lesser extent by the gracile Enallhelia (17\%). Microbialites, representing 39\% of the reef surface, also strongly contributed to the framework composition in these small bioherms. A facies belt of oncoidal sediments is observed in more proximal area of the mid ramp, between these coral meadows and the ooidal shoal (Olivier et al. 2011).

\section{Ox7 model of coral reef distribution}

The second model of reef distribution along the French Jura platform occurred during the medium-scale sequence Ox7 (Olivier et al. 2015). Coral buildups are still observed in inner (Loulle) and mid ramp (Loulle, Morillon, and Molinges) settings (Fig. 12). The inner ramp area was probably of more limited scale (Olivier et al. 2015), only allowing the growth of some biostromes (Loulle reef growth phase 3.3) that were not able to exceed ten centimetres in thickness and a few metres in length. Their internal structure is dominated by a dense framework (55\% of the reef surface) made of corals and microbialites, but the sediment cover is also important (45\%; Cariou 2013). Microsolena $(24 \%)$ is the characteristic genus of these inner ramp biostromes, which are moderately diversified, with 14 coral genera identified. Stylinids are

Table 1. Litho- and biostratigraphy, and sequential framework of the French Jura Mountains during the Oxfordian (after Olivier et al. 2015).

\begin{tabular}{|c|c|c|c|c|c|c|c|c|}
\hline : & \multirow{2}{*}{\multicolumn{2}{|c|}{\begin{tabular}{|c}
$\begin{array}{c}\text { Sub-mediterranean } \\
\text { zonation }\end{array}$ \\
Ammonites
\end{tabular}}} & \multicolumn{3}{|c|}{ French Jura } & \multicolumn{3}{|c|}{$\begin{array}{l}\text { Sequential } \\
\text { framework }\end{array}$} \\
\hline \multirow{3}{*}{ 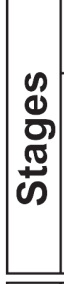 } & & & \multicolumn{3}{|c|}{$\begin{array}{l}\text { Lithostratigraphy } \\
\text { (after Olivier et al. 2015) }\end{array}$} & & & \\
\hline & \multirow{2}{*}{ Zones } & \multirow[t]{2}{*}{ Sub-zones } & \begin{tabular}{|c|} 
Northern \\
Jura
\end{tabular} & & Central Jura & Sout & $\begin{array}{l}\text { hern } \\
\text { ira }\end{array}$ & 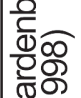 \\
\hline & & & \begin{tabular}{|c|}
$\mathrm{Fm}$ \\
\end{tabular} & Fm & $\mathrm{Mb}$ & Fm & $\mathrm{Mb}$ & INE \\
\hline \multirow{5}{*}{$\begin{array}{l}\frac{c}{\sqrt[0]{0}} \\
\frac{0}{0} \\
\frac{0}{0} \\
\frac{0}{x} \\
0\end{array}$} & \multirow{5}{*}{$\begin{array}{l}\text { Bimam- } \\
\text { matum }\end{array}$} & Hauffianum & \multirow{5}{*}{ 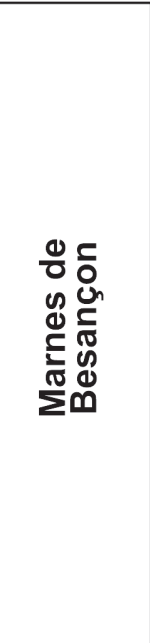 } & \multirow{4}{*}{ 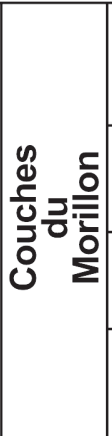 } & $\begin{array}{l}\text { Calcaires } \\
\text { de Loulle }\end{array}$ & \multirow{5}{*}{ 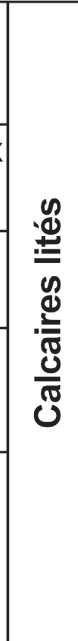 } & \multirow{4}{*}{ 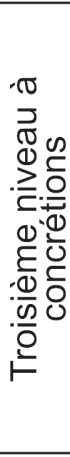 } & \multirow{5}{*}{$\begin{array}{l}-0 \times 7 . \\
-0 \times 6+\end{array}$} \\
\hline & & $\begin{array}{l}\text { Bimam- } \\
\text { matum }\end{array}$ & & & $\begin{array}{l}\text { Calcaires marneux } \\
\text { récifaux de Loulle }\end{array}$ & & & \\
\hline & & \multirow{2}{*}{ Berrense } & & & $\begin{array}{l}\text { Calcaires } \\
\text { blancs du } \\
\text { Mont Rivel }\end{array}$ & & & \\
\hline & & & & & $\begin{array}{l}\text { Oolithe du } \\
\text { Mont Rivel }\end{array}$ & & & \\
\hline & & $\begin{array}{l}\text { Semimam- } \\
\text { matum }\end{array}$ & & 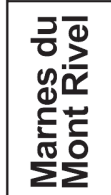 & & & & \\
\hline
\end{tabular}


relatively well represented, particularly by the Stylina genus, whose specimens tend to display ramose forms. In this inner ramp setting, the sedimentation was dominated by peloidal packstones, suggesting a shallow environment (Cariou et al. 2014).

A large mid ramp allowed the development of a fairly wide variety of reef structures (Fig. 12). In the more proximal part of the mid ramp the plurimetric- to decametricscale bioherms of Loulle developed (i.e. reef growth phases 1 and 2). In these bioconstructions the coral and microbialite framework makes up the majority of the surface (90\%; Cariou 2013). Coral cover reaches nearly $60 \%$ of the reef surface, whereas the sediment cover does not exceed $10 \%$. With 21 genera identified, coral diversity is relatively high. The coral assemblage is mainly represented by common Microsolena, Thamnasteria, and some stylinids. The Morillon reefs, at an intermediate position along the mid ramp, did not develop widely, with only small $\mathrm{dm}$ - to $\mathrm{m}$-scale patches. The coral assemblage here is relatively diversified, with 18 genera identified. Corals are mainly represented by massive and lamellar forms of Microsolena (25\%) and Thamnasteria (18\%). These reefs developed in marly limestones rich in peloids and oncoids with some megaripples (Cariou 2013). Reefs observed at Molinges (reef units 6 and 7) occur even in the distal part of the mid ramp (Olivier et al. 2011). These reefs do not show any significant evolution compared to those in the Ox6+ sequence. They have the same biostromal morphology, and a high coral diversity with 20 genera identified. There is still a high proportion of dendroid colonies belonging to the genus Enallhelia $(35 \%)$. A marly oncoidal facies belt characterized the most distal part of the mid ramp, with marl-limestone alternations deposited below the storm wave base level (Olivier et al. 2011).

\section{Controlling factors}

During the Late Jurassic, the Jura platform was located at a latitude of about $27-28^{\circ} \mathrm{N}$ (Frakes et al. 1992, Cecca et al. 1993), where a subtropical climate was usually very favourable to carbonate sedimentation (Tucker \& Wright 1990). In such a palaeogeographical setting, intense carbonate sedimentation led to recurrent phases of progradation of the French Jura platform (Enay 1966, Bernier 1984, Enay et al. 1988, Cochet et al. 1994, Reolid et al. 2007, Olivier et al. 2015). However, the present analysis of coral growth during the Bimammatum Zone (Late Jurassic) reveals that the reef development was never optimal, indicating various environmental stresses. Observed reefs at the Mont Rivel locality only developed biohermal structures of 3 to 4 metres thick and 5 to 15 metres long. These are modest dimensions compared to other
Late Jurassic platforms where coral-microbialite reefs reached 10 to 15 metres thick and extended over more than a hundred metres laterally, for example in the Oxfordian of Lorraine (Geister \& Lathuilière 1991, Carpentier 2004, Olivier et al. 2004a, Martin-Garin 2005, Carpentier et al. 2010, Martin-Garin et al. 2012). In the Late Jurassic, climate changes, notably in terms of humidity, led to variations in the amount of rain on the continents and in the flow of material draining on to the Jura platform (Pittet \& Strasser 1998, Cecca et al. 2005). Epicontinental seas were subject to terrigenous inputs, and thus recorded variations in the trophic conditions which in turn controlled reef composition and development (Dupraz 1999; Dupraz \& Strasser 1999, 2002; Leinfelder et al. 2002; Olivier et al. 2007).

\section{Reef development under a low to moderate terrigenous input}

During the medium scale sequence Ox6+, the climate was relatively dry and hot and terrigenous inputs were low along the French Jura platform (Olivier et al. 2015). The carbonate production was particularly important, notably in the inner ramp position where a large ooidal shoal complex developed (Fig. 13). It was in this type of environment that coral reefs reached the largest dimensions observed during the Bimammatum Zone (i.e. ten metres wide and a few metres thick; Fig. 2). An ooidal shoal system is generally regarded as reflecting clear, nutrient-deficient (oligotrophic) waters (Diaz et al. 2014), which are particularly well adapted to a high rate of coral growth (Mutti \& Hallock 2003). Several Mount Rivel coral colonies are large in size and of high skeletal density (e.g. the genus Isastrea), highlighting major reef framework development. Petrographic analysis of the ooidal sediments at Mount Rivel nevertheless reveals the presence of some quartz grains (Cariou 2013, Olivier et al. 2015). Thus, the water column was probably not totally devoid of terrigenous material and associated nutrients, notably if siliciclastic sediments were trapped in more proximal areas or could be carried outside the ooidal shoal by tide and wave actions (Tucker \& Wright 1990, Larcombe \& Woolfe 1999). The low diversity (only 7 genera) coral assemblage of the Mont Rivel reefs is composed in particular of the genera Thamnasteria and Microsolena, as well as some stylinids (Stylina and Stylosmilia; Fig. 3A). While stylinids are classically associated with nutrient-poor waters (Dupraz 1999), corals of the genus Microsolena are considered to be suspensionfeeder organisms well adapted to low light irradiation (Lathuilière \& Gill 1995). Considering that Thamnasteria occupies a very large eco-space (Bertling 1993), the coral assemblage at Mont Rivel is consistent with a balanced 


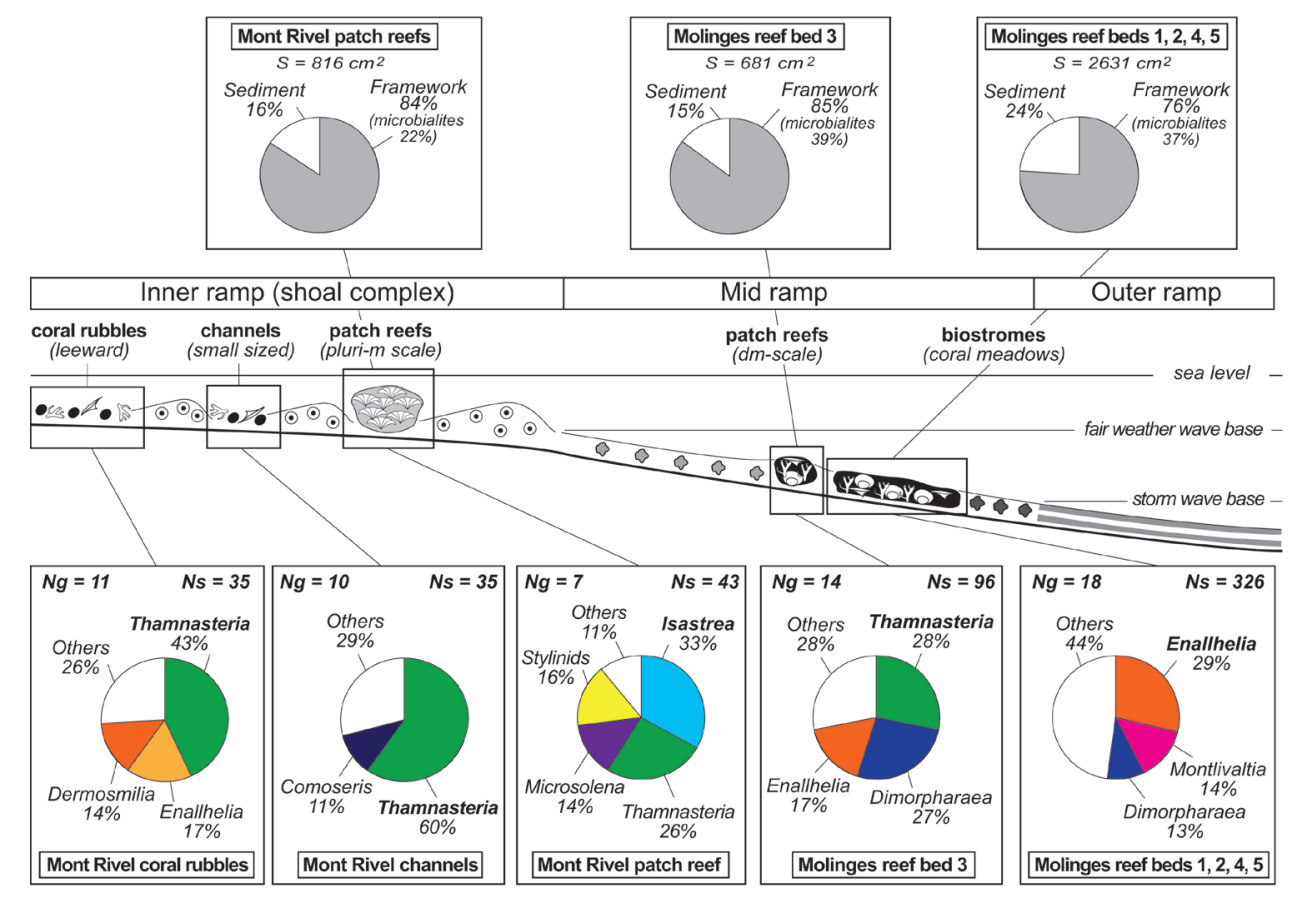

Figure 11. Distribution of coral buildups along the French Jura platform during the sequence Ox6+. In the inner ramp zone, coral buildups or accumulations are observed in different positions in a large shoal complex. The mid ramp is characterized by small patch reefs in its central part and by coral meadows in its distal part (see the text for more explanation). Only the most abundant genera (i.e. $>10 \%$ of the coral assemblage) are reported. Reef surface estimation of the main reef components is after López (2011) and Cariou (2013) for Loulle and Mont Rivel, and after Olivier et al. (2011) for Molinges. Abbreviations: S - reef surface studied; Ns - number of specimens; Ng - number of genera. Same legend as Fig. 13.

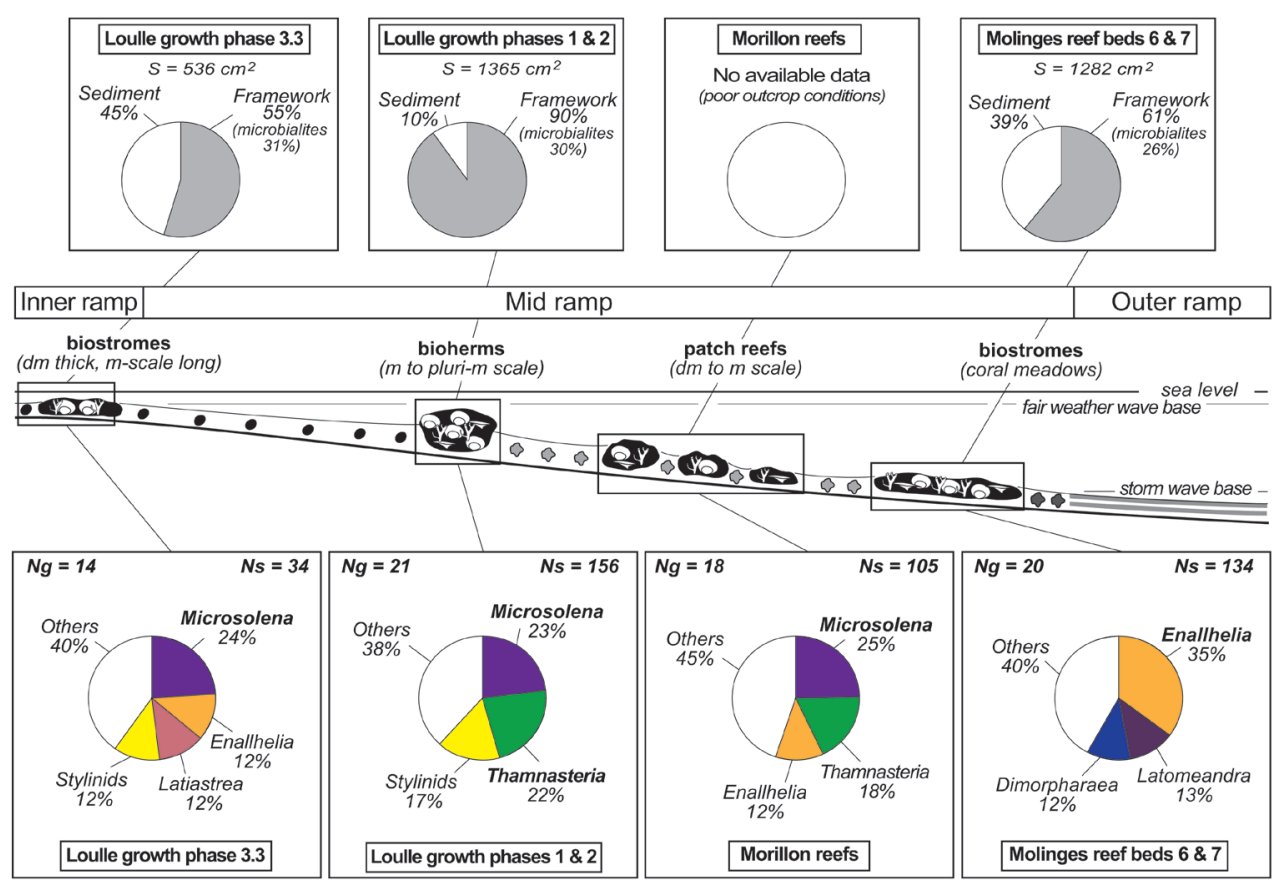

Figure 12. Distribution of coral buildups along the French Jura platform during the sequence Ox 7 . On the internal ramp, only the small biostromes from Loulle are observed. Three types of reefs are observed along the mid ramp; the Loulle bioherms in a proximal position, the small patches of Morillon in intermediate position, and the Molinges coral meadows in the distal part. Only the most abundant genera (i.e. $>10 \%$ of the coral assemblage) are shown. Reef surface estimation of the main reef components is after López (2011) and Cariou (2013) for Loulle and Mont Rivel, and after Olivier et al. (2011) for Molinges. Abbreviations: S - reef surface studied; Ns - number of specimens; $\mathrm{Ng}$ - number of genera. Same legend as Fig. 13. 
heterotrophic/phototrophic mode of nutrition (Dupraz \& Strasser 2002, Olivier et al. 2004a), confirming a certain amount of nutrients in the water column. Microbialites constitute nearly a quarter of the volume of the Mont Rivel reef (Fig. 11). When microbialites are observed in coral reefs, their development is often equated with the presence of nutrients (Dupraz \& Strasser 1999, 2002; Sprachta et al. 2001; Cabioch et al. 2006; Camoin et al. 2006; Olivier et al. 2007; Zamagni et al. 2009). In some Jurassic coral reef ecosystems, such microbialite development probably implied relatively long periods when waters became sufficiently nutrient-rich to enable microbial blooms to form (Dupraz 1999, Olivier et al. 2011). Such periods contributed to reducing the time over which the environment was favourable to coral growth, thus limiting the primary reef framework development.

The tide-dominated ooidal shoal complex of Mount Rivel also reflects the higher hydrodynamic energy environments observed along the French Jura platform during the Bimammatum Zone (Olivier et al. 2015). The presence of relatively high proportions of corals such as Isastrea in these bioherms is consistent with other highenergy Jurassic reefs in which this genus is also well represented (Insalaco 1999, Dupraz \& Strasser 2002, Martin-Garin 2005). The development of coral reefs in ooidal sedimentary systems was not unusual during the Late Jurassic (Bertling \& Insalaco 1998, Insalaco 1999, Lathuilière et al. 2005, Reolid et al. 2009), even though it is quite rare nowadays. Such an association is observed, for example, at Joulter Cay in northern Andros Island (Bahamas), where coral patches are only located seaward of the ooidal shoals (Tucker \& Wright 1990). Several studies conducted on ancient sedimentary systems have similarly illustrated the presence of coral reef formations at the front of prograding ooidal shoals (Aurell \& Bádenas 2004, Betzler et al. 2007). However, it is more difficult to think of coral reefs developing within the ooidal system itself. Considering the instability of the substrate in an ooidal bar subjected to the action of the tides and the swell, and its strong capacity to migrate, it would seem unlikely to find corals or even reefs located in such a highenergy setting (Lathuilière et al. 2005, Reolid et al. 2009). The study of the Oxfordian sedimentary succession of Bonnevaux-le-Prieuré (northern French Jura) enabled Lathuilière et al. (2005) to reconstruct a zoned coral complex where a tide-dominated ooidal shoal occupied a central position (i.e. where water energy was the highest) and where corals were mainly distributed on either side of this barrier. However, a tidal sedimentary system with coexisting coral patches and ooidal bars can currently be observed in Abu Dhabi along the southeast coast of the Persian Gulf (Purser 1983). Towards the coast, the central tidal channel of the ooidal Abu Dhabi barrier contains numerous coral patches and coarse ooidal and bioclastic sands. The location of coral reefs in the ooidal shoal of Mount Rivel, however, was significantly different. They did not develop in a large or major (unseen) channel, nor within the many observed small channels. Corals are well represented in the latter, but only as reworked elements, highlighting an environment which was too high-energy for their implantation and growth. At Mont Rivel, the implantation of coral patches initiated on largearea sedimentary surfaces between ooidal dunes (Fig. 2). The establishment of corals and the construction of a reef framework would have required relatively long periods of time during which the ooidal sediments were sufficiently stable. However, carbonate sedimentation in shallow epicontinental seas was commonly affected by tides and storms (Pratt \& James 1986), making potential preservation of reef formations in such sedimentary environments difficult. It is thus necessary to take into account the complex pattern of juxtaposed environments observed on carbonate platforms that commonly leads to a patchy facies distribution (i.e. facies mosaic; Strasser \& Védrine 2009). In a sedimentary system such as the ooidal shoal complex of Mont Rivel, low energy levels that allowed reef development may have occurred in protected interdune areas or along minor and low-energy tidal channels. Thus, the spatial and temporal distribution of the Mont Rivel reefs was probably controlled by stochastic and autocyclic processes (Rankey 2002, Wright \& Burgess 2005). Considering that daily tides have a limited effect on sedimentation compared to the influence of major storms on epicontinental basins (Pratt \& James 1986), the final demise of the Mont Rivel reefs could be explained by aperiodic storm events. These latter could have triggered rapid and major migrations of the ooidal dunes that were able to definitively cover coral reef patches, thus limiting their size.

\section{Reef development with a moderate- to high-terrigenous input}

During the Ox7 sequence, the climate was significantly more humid (Olivier et al. 2015), draining more terrigenous material on to the French Jura platform (Fig. 13). In this mixed siliciclastic-carbonate system, terrigenous supplies may have had an impact on the reef ecosystems, in particular by changing turbidity, light intensity and trophic conditions. The analysis of coral assemblages provides a preliminary set of information on the depositional environment, in particular in terms of trophic conditions. Dupraz \& Strasser (2002), like Leinfelder et al. (1996), observed that the most diverse Jurassic coral reefs developed when some terrigenous material and associated nutrients were present in the environment. The different reefs observed along the French Jura platform 


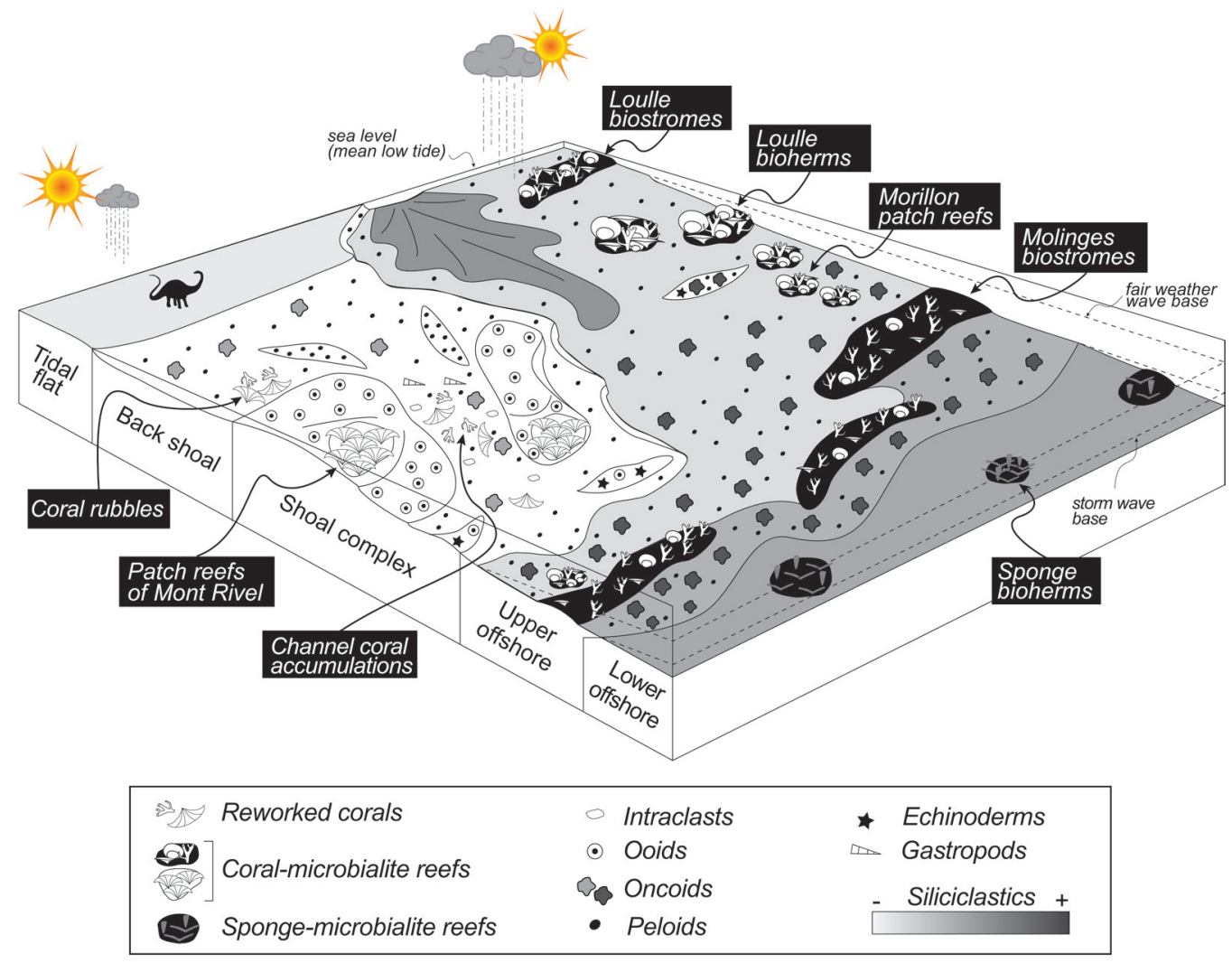

Figure 13. Schematic 3D reconstruction of the depositional environments for coral reefs along the French Jura platform during the Bimammatum Zone.

during Ox7 can be very diversified (up to 21 genera). Whatever their position along the platform, all these reefs are commonly composed of microsolenids and stylinids, highlighting mixed photo-heterotrophic coral assemblages and nutrient supplies (Olivier et al. 2004a). In nutrientrich waters, the hypothesis that some Jurassic corals had a facultative symbiosis with zooxanthellae and shifted from autotrophic to heterotrophic behaviour, cannot be rejected (Gretz et al. 2013). Nowadays, azooxanthellate colonies capable of participating in the building of reef frameworks are notably represented by dendroid morphologies of the genus Lophelia (Chevalier 1987, Stanley \& Cairns 1988, Cairns \& Kitahara 2012). In the distal part of the mid ramp, Molinges coral meadows were made of a large proportion of Enallhelia (35\% of the coral assemblage), which reinforces the hypothesis of an apozooxanthellate character for these dendroid corals (Gill et al. 2004). Depending on whether zooxanthellae are present or not, corals have a different growth potential (Gill et al. 2004), and do not have the same capacity to build reef structures (Stanley 2003, Dullo 2005). Thus, under conditions with significant terrigenous and nutrient input, this higher proportion of heterotrophs in the coral population at increased depth and decreased light intensity is consistent with the lower coral and reef sizes observed along the French Jura platform during the Bimammatum Zone (Figs 12, 13).

In such mixed carbonate-siliciclastic systems, some reefs observed along the French Jura platform display numerous surfaces of growth interruption, highlighting a temporally irregular and non-continuous development. This is particularly marked for the inner to mid ramp reefs of Loulle that developed laterally into marl-limestone alternations (Fig. 4). The successive reef growth phases are thus correlated with limestone beds, whereas marly levels correspond to reef growth interruptions. The deposition of marls implies higher siliciclastic inputs and more nutrient-rich waters, probably triggered by a more humid climate (Olivier et al. 2007). Thus, allocyclic processes clearly controlled the reef development in this inner to mid ramp position. At Morillon (i.e. in a more central position along the mid ramp), marly interbeds are less well individualized (Fig. 7), highlighting a greater distance from terrigenous sources and higher non-reefderived sediment production with significant accumulation of oncoids (Figs 12, 13). The final demise of the Morillon patch reefs may still have been caused by the deposition of marls, but they are also capped by some oncoidal megaripples. Thus, lateral migration of oncoidal bodies during storm events may have been responsible for 
the final demise of these mid ramp reefs. This highlights that further away from terrigenous input (i.e. in the central part of the mid ramp), the reefs of the French Jura platform potentially recorded an influence of autocyclic factors. Molinges coral meadows, located in the distal part of the mid ramp, appear to have developed over large areas and do not show clear internal surfaces that might reflect reef growth interruptions. Their growth appears to have been relatively continuous over longer periods of time, until they were finally capped by thin marly intervals or by thicker oncoidal beds (Fig. 9). In this distal part of the mid ramp, the depositional sequences and reef development do not record any influence from autocyclic processes and were clearly allocyclic and Milankovitch driven (Olivier et al. 2011). Indeed, the accumulation of marls were triggered by periods when climate was more humid, whereas prograding oncoidal facies belts might have covered the coral meadows following a decreasing rate of sea level rise (Olivier et al. 2011). On the outer ramp, sponge-microbialite bioherms developed alongside marl-limestone alternations (Gaillard 1983, Olivier et al. 2007). In such distal position, the growth of spongemicrobialite bioherms was also controlled by allocyclic and Milankovitch-driven fluctuations in the trophic conditions associated with clay-rich intervals (Olivier et al. 2004b).

The most proximal position of the French Jura platform during the Bimammatum Zone was occupied by the biostromal reefs of Loulle, which do not exceed a few decimetres in thickness (Figs 4C, 12, 13; Cariou et al. 2014, Olivier et al. 2015). This suggests that depth and accommodation were probably highly limiting. These biostromes are made of common Stylina colonies with branching morphologies, which reflect shallow and wellilluminated waters (Insalaco 1996). In the most proximal part of the mid ramp position, the Loulle reefs developed biohermal morphologies that reached several meters wide and thick (Fig. 4A, B), suggesting that accommodation was no longer a limiting factor. In these bioherms, certain stylinid genera (i.e. Stylina, Pseudocoenia and Stylosmilia) represent $\sim 20 \%$ of the coral assemblage (Figs 5, 6). The presence of stylinids in Jurassic reefs is classically interpreted as being characteristic of euphotic environments (Lathuilière et al. 2005, Martin-Garin et al. 2007, Reolid et al. 2009). Thus, the Loulle bioherms indicate that the water column in the proximal part of the mid ramp was not turbid and that light intensity was still high and did not limit reef growth. The Morillon reefs developed in a more central position along the mid ramp and stylinids only represent less than $10 \%$ of their coral assemblage (Fig. 8). Such a decrease in the proportion of stylinids is consistent with progressive light attenuation along the mid ramp as the depth increased. Leinfelder $e t$ al. (1996) indicated that as the lower limit of the euphotic zone approached, many Jurassic coral taxa disappeared and flat colonies of microsolenids began to dominate the community, associated with lithistid sponges. Among the Jurassic microsolenids, corals of the genus Dimorpharaea were able to develop large flat morphologies that were adapted to low-light intensities notably in deeper water (Insalaco 1996, Leinfelder et al. 1996, Gill et al. 2004, Lathuilière et al. 2005, Martin-Garin et al. 2007, Olivier et al. 2012). In the most distal parts of the mid ramp, Molinges coral meadows only contain a small proportion of lithistid sponges (Olivier et al. 2011). Moreover, corals of the genus Dimorpharaea were present (Fig. 10), but they did not develop typical platy morphologies (Olivier et al. 2011). This probably indicates that even in the presence of terrigenous input, the distal parts of the French Jura mid ramp were still above the lower limit of the euphotic zone. This hypothesis is consistent with Gaillard (1983)'s observations of sponge bioherms along the distal and outer French Jura platform, where microbialites always display a vertical growth direction, reflecting the presence of light.

\section{Conclusions}

1) Based on a recent and detailed stratigraphic framework, this work illustrates the composition and distribution of coral-microbialite reefs along the French Jura platform in a single ammonite zone, the Bimammatum Zone of the Upper Oxfordian. Diversified coral-microbialite reefs developed in various environments of inner and mid ramp settings, while sponge bioherms occurred in the more distal parts of the platform.

2) Depending on the terrigenous input, two sedimentary systems can be identified along the French Jura platform. Under reduced to moderate terrigenous inputs (sequence Ox6+), the inner ramp setting was characterized by the development of an important ooidal shoal complex, in which ten-meter large coral-microbialite patches occurred. Most of the narrow mid ramp was characterized by coral-microbialite meadows, with some rare $\mathrm{dm}$-scale bioherms in its most proximal part. Under moderate to high terrigenous inputs (sequence Ox7), the shallow inner ramp was characterized by the development of coralmicrobialite reefs with a biostromal morphology. Various buildups occurred along a wide mid ramp. In its most proximal parts there were $\mathrm{m}$ - to several-m scale coralmicrobialite bioherms. In its central part, corals only formed small dm-scale patches, whereas in its most distal part coral-microbialite meadows flourished.

3) Regardless of the depositional setting and the amount of terrigenous material considered, the different observed reefs are composed of mixed photo-heterotrophic coral 
assemblages. Patch reefs observed in the ooidal shoal complex (almost devoid of terrigenous material) display a low diversity coral assemblage (only 7 genera). In these shallow, agitated waters, some high-density skeletal corals of the genus Isastrea largely contributed to the reef framework, together with some stylinids, Thamnasteria and Microsolena. In a mixed siliciclastic-carbonate system, the different studied reefs have a greater coral diversity (up to 21 genera). Stylinids, Microsolena and Thamnasteria are still well represented in reefs on the inner ramp and the most proximal part of the mid ramp. Further along the mid ramp, stylinids disappear, and Enallhelia becomes the most common taxa in the coral meadows, emphasizing a higher proportion of heterotrophic coral colonies that had a lower capacity to build reef structures.

4) Reef development during the Bimammatum Zone was never optimal, highlighting the limiting effects of several environmental parameters. In the most proximal and shallowest area of the inner ramp, reduced space prevented efficient coral reef growth, leading to the development of thin biostromal units. In an ooidal shoal complex, the high sediment production and the autocyclic character (i.e. dune migration following big storm events) of this sedimentary system limited the periods of reef development and thus the final size of the coral bioherms. When the sedimentary system was submitted to higher terrigenous supplies, turbidity and trophic conditions led to interruptions in reef growth and ultimately their final demise. This allocyclic influence was particularly wellmarked in inner, most proximal and most distal mid ramp zones, but was less important in the central part of the mid ramp. In this latter position, at a sufficient distance from terrigenous sources, higher oncoidal sediment production and its transport during storms (i.e. autocyclic process) are inferred to have been the limiting factors with regard to coral reef development. In the most distal part of the mid ramp, the reef development was also controlled by allocyclic processes such as seal level variations, which led to progradation of oncoidal facies belts over the coral meadows.

\section{Acknowledgments}

I thank the Geology Laboratory of Lyon (LGLTPE) for its financial support for the field missions and sample preparation. I am grateful to Julie Lattaud and Mathieu Lefèvre who completed an internship to familiarize with the determination of corals. Jesús López, Elsa Cariou and Alex Lena are thanked for their work in the field and their help in sampling. I am particularly indebted to Jesús López and Elsa Cariou who logged several sections where reefs are present, analysed facies, prepared some coral samples and estimated the reef component abundances for some reef localities. Without the participation of my former students, this present work and synthesis would not have been possible. Thanks to Claude Colombié and Bernard Pittet for the many scientific discussions on sedimentology and Late Jurassic carbonates. I want to thank Bernard Lathuilière for his explanations of the systematics of Jurassic corals. This work would not have happened without the help of Pierre Hantzpergue and his knowledge of the geology of the Jura Mountains. I thank Fran van Wyk de Vries for reviewing the English of this manuscript. Constructive reviews by Marcos Aurell and Matías Reolid significantly improved the manuscript.

\section{References}

Aurell, M. \& Bádenas, B. 2004. Facies and depositional sequence evolution controlled by high-frequency sea-level changes in a shallow-water carbonate ramp (late Kimmeridgian, NE Spain). Geological Magazine 141, 717-733. DOI 10.1017/S0016756804009963

BÁdenas, B. \& Aurell, M. 2010. Facies models of a shallowwater carbonate ramp based on distribution of non-skeletal grains (Kimmeridgian, Spain). Facies 56, 89-110. DOI 10.1007/s10347-009-0199-z

Beauvais, L. \& Bernier, P. 1981. Nouvelles espèces de Madréporaires dans le Kimméridgien supérieur du Jura (France). Geobios 14, 173-189. DOI 10.1016/S0016-6995(81)80002-2

Beresi, M.S., Cabaleri, N.G., Löser, H. \& Armella, C. 2017. Coral patch reef system and associated facies from southwestern Gondwana: paleoenvironmental evolution of the Oxfordian shallow-marine carbonate platform at Portada Covunco, Neuquén Basin, Argentina. Facies 63, p. 4. DOI 10.1007/s10347-016-0486-4

BERTLING, M. 1993. Ecology and distribution of the Late Jurassic Scleractinian Thamnasteria concinna (Goldfuss) in Europe. Palaeogeography, Palaeoclimatology, Palaeoecology 105, 311-335. DOI 10.1016/0031-0182(93)90088-Z

Bertling, M. \& Insalaco, E. 1998. Late Jurassic coral/microbial reefs from the northern Paris Basin: facies, palaeoecology and palaeobiogeography. Palaeogeography, Palaeoclimatology, Palaeoecology 139, 139-175.

DOI 10.1016/S0031-0182(97)00125-9

Bernier, P. 1984. Les formations carbonatées du Kiméridgien et du Portlandien dans le Jura méridional, stratigraphie, micropaléontologie sédimentologie. Documents du Laboratoire de Géologie de Lyon 92, 1-883.

Betzler, C., Pawellek, T., Abdullah, M. \& Kossler, A. 2007. Facies and stratigraphic architecture of the Korallenoolith Formation in North Germany (Lauensteiner pass, Ith mountains). Sedimentary Geology 194, 61-75.

DOI 10.1016/j.sedgeo.2006.05.002

Bill, M., O’Dogherty, L. \& Baumgartner, P.O. 2011. Dynamics of a paleoecosystem reef associated with oceanic change in carbonate sedimentary regime and carbon cycling (Oxfordian, Swiss Jura). Palaios 26, 197-211.

DOI 10.2110/palo.2010.p10-063r 
Cabioch, G., Camoin, G., Webb, G.E., Le Cornec, F., Molina, M.G., Pierre, C. \& Joachimski, M.M. 2006. Contribution of microbialites to the development of coral reefs during the last deglacial period: case study from Vanuatu (South-West Pacific). Sedimentary Geology 185, 297-318.

DOI 10.1016/j.sedgeo.2005.12.019

Camoin, G., Cabioch, G., Eisenhauer, A., Braga, J.C., Hamelin, B. \& Lericolais, G. 2006. Environmental significance of microbialites in reef environments during the last deglaciation. Sedimentary Geology 185, 277-295.

DOI 10.1016/j.sedgeo.2005.12.018

Cairns, S.D. \& Kitahara, M.V. 2012. An illustrated key to the genera and subgenera of the Recent azooxanthellate Scleractinia (Cnidaria, Anthozoa), with an attached glossary. Zookeys 227, 1-47.

CARIOU, E. 2013. La plateforme jurassienne au passage Oxfordien-Kimméridgien: dynamique sédimentaire et paléoenvironnements. 337 pp. Ph.D. thesis, Université Claude Bernard Lyon 1, Villeurbanne, France.

Cariou, E., Olivier, N., Pittet, B., Mazin, J.M. \& Hantzpergue, P. 2014. Dinosaur track record on a shallow carbonatedominated ramp (Loulle section, Late Jurassic, French Jura). Facies 60, 229-253. DOI 10.1007/s10347-013-0368-y

CARPENTIER, C. 2004. Jurassic coral reefs of the north-eastern Paris Basin (Luxembourg and Lorraine). 471 pp. Ph.D. thesis, Université Henri Poincaré Nancy I, Nancy, France.

Carpentier, C., Lathuilière, B. \& Ferry, S. 2010. Sequential and climatic framework of the growth and demise of a carbonate platform: implications for the peritidal cycles (Late Jurassic, North-eastern France). Sedimentology 57, 985-1020. DOI 10.1111/j.1365-3091.2009.01128.x

Carpentier, C., Martin-Garin, B., Lathuilière, B. \& Ferry, S. 2006. Correlation of reefal Oxfordian episodes and climatic implications in the eastern Paris Basin (France). Terra Nova 18, 191-201. DOI 10.1111/j.1365-3121.2006.00679.x

Cecca, F., Azema, J., Fourcade, E., Baudin, F., Guiraud, R., Ricou, L.E. \& De Wever, P. 1993. Early Kimmeridgian (146-144 Ma). In Dercourt, J., Ricou, L.E. \& Vrielynck, B. (eds) Atlas of Tethys Palaeoenvironmental Maps. Maps. BEICIP-FRANLAB, Rueil-Malmaison.

Cecca, F., Martin-Garin, B., Marchand, D., Lathuilière, B. \& BArtolini, A. 2005. Paleoclimatic control of biogeographic and sedimentary events in Tethyan and peri-Tethyan areas during the Oxfordian (Late Jurassic). Palaeogeography Palaeoclimatology Palaeoecology 222, 10-32.

DOI 10.1016/j.palaeo.2005.03.009

Chevalier, J.-P. 1987. Ordre des Scléractiniaires, 403-764. In Grassé, P.-P. (ed.) Traité De Zoologie: Anatomie, Systématique, Biologie. 3. Cnidaires Anthozoaires. Masson, Paris.

Cochet, F. 1995. Stratigraphie séquentielle dans les carbonates de l'Oxfordien terminal-Kimméridgien du Jura français. 200 pp. Ph.D. thesis, Université Claude Bernard Lyon 1, Villeurbanne, France.

Cochet, F., Ferry, S., Enay, R. \& Contini, D. 1994. Passage Oxfordien-Kimméridgien dans les carbonates du Jura français au Bassin vocontien. Régression forcée et cortège transgressif.
Comptes Rendus de l'Académie des Sciences série II 319, 1041-1047.

Colombié, C. \& Strasser, A. 2005. Facies, cycles, and controls on the evolution of a keep-up carbonate platform (Kimmeridgian, Swiss Jura). Sedimentology 52, 1207-1227. DOI 10.1111/j.1365-3091.2005.00736.x

Diaz, M.R., Van Norstrand, J.D., Eberli, G.P., Piggot, A.M., Zhou, J. \& KLAUS, J.S. 2014. Functional gene diversity of oolitic sands from Great Bahama Bank. Geobiology 12, 231-249. DOI $10.1111 /$ gbi.12079

Dullo, W.-C. 2005. Coral growth and reef growth: a brief review. Facies 51, 33-48. DOI 10.1007/s10347-005-0060-y

Dupraz, C. 1999. Paléontologie, paléoécologie et évolution des faciès récifaux de l'Oxfordien moyen-supérieur (Jura suisse et français). Geofocus 2, 1-200.

Dupraz, C. \& Strasser, A. 1999. Microbialites and microencrusters in shallow coral bioherms (Middle to Late Oxfordian, Swiss Jura Mountains). Facies 40, 101-130. DOI 10.1007/BF02537471

Dupraz, C. \& Strasser, A. 2002. Nutritional modes in coral microbialite reefs (Jurassic, Oxfordian, Switzerland): evolution of trophic structure as a response to environmental change. Palaios 17, 449-471.

DOI 10.1669/0883-1351(2002)017<0449:NMICMR>2.0.CO;2

EnAY, R. 1966. L'Oxfordien dans la moitié sud du Jura français. Etude stratigraphique. Nouvelles Archives du Muséum d'histoire naturelle de Lyon 8, 1-624.

Enay, R., Contini, D. \& Boullier, A. 1988. Le Séquanientype de Franche-Comté (Oxfordien supérieur): datations et corrélations nouvelles, conséquences sur la paléogéographie et l'évolution du Jura et régions voisines. Eclogae Geologicae Helvetiae 81, 295-363.

FooKes, E. 1995. Development and eustatic control of an Upper Jurassic reef complex (Saint Germain-de-Joux, Eastern France). Facies 33, 129-149. DOI 10.1007/BF02537448

Frakes, L.A., Francis, J.E. \& Syktus, J.I. 1992. Climate Modes of the Phanerozoic: The History of the Earth's Climate Over the Past 600 million Years. 274 pp. Cambridge University Press, Cambridge. DOI 10.1017/CBO9780511628948

Gaillard, C. 1983. Les biohermes à Spongiaires et leur environnement dans l'Oxfordien du Jura méridional. Documents $d u$ Laboratoire de Géologie de Lyon 90, 1-515.

Geister, J. \& Lathuilière, B. 1991. Jurassic coral reefs of the north-eastern Paris Basin (Luxembourg and Lorraine). VI International Symposium on Fossil Cnidaria, Münster, Guidebook-Excursion.

Gill, G.A., Santantonio, M. \& Lathuilière, B. 2004. The depth of pelagic deposits in the Tethyan Jurassic and the use of corals: an example from the Apennines. Sedimentary Geology 166, 311-334. DOI 10.1016/j.sedgeo.2004.01.013

Gretz, M., Lathuilière, B., Martini, R. \& Bartolini, A. 2013. The Hettangian corals of the Isle of Skye (Scotland): An opportunity to better understand the palaeoenvironmental conditions during the aftermath of the Triassic-Jurassic boundary crisis. Palaeogeography, Palaeoclimatology, Palaeoecology 376, 132-148.

DOI 10.1016/j.palaeo.2013.02.029 
Habrant, N. \& Lathuilière, B. 2000. Jurassic corals as emersion indicators. Lethaia 33, 341-344.

DOI 10.1080/002411600750053907

Hardenbol, J., Thierry, J., Farley, M.B., Graciansky, P.C. DE \& VAIL, P.R. 1998. Mesozoic and Cenozoic sequence chronostratigraphic framework of European basins, 3-13. In Graciansky, P.C. DE, Hardenbol, J., Jacquin, T. \& Vail, P.R. (eds) Mesozoic and Cenozoic sequence stratigraphy of European basins. SEPM Special Publication 60.

DOI 10.2110/pec.98.02.0003

Helm, C. \& Schülke, I. 2006. Patch reef development in the florigemma-Bank Member (Oxfordian) from the Deister Mts (NW Germany): a type example for Late Jurassic coral thrombolite thickets. Facies 52, 441-467.

DOI 10.1007/s10347-006-0078-9

Hug, W. 2003. Sequenzielle Faziesentwicklung der Karbonatplattform des Schweizer Jura im Späten Oxford und frühesten Kimmeridge. GeoFocus 7, Univ. Fribourg, 1-155.

InsALACO, E. 1996. Upper Jurassic microsolenid biostromes of northern and central Europe: facies and depositional environment. Palaeogeography, Palaeoclimatology, Palaeoecology 121, 169-194.

DOI 10.1016/0031-0182(95)00072-0

InsALACO, E. 1999. Facies and palaeoecology of Upper Jurassic (Middle Oxfordian) coral reefs in England. Facies 40, 81-99. DOI 10.1007/BF02537470

Insalaco, E., Hallam, A. \& Rosen, B. 1997. Oxfordian (Upper Jurassic) coral reefs in Western Europe: reef types and conceptual depositional model. Sedimentology 44, 707-734. DOI 10.1046/j.1365-3091.1997.d01-44.x

Larcombe, P. \& Woolfe, K.J. 1999. Increased sediment supply to the Great Barrier Reef will not increase sediment accumulation at most coral reefs. Coral Reefs 18, 163-169. DOI 10.1007/s003380050174

Lathuilière, B. \& Gill, G.A. 1995. Some new suggestions on functional morphology in pennular corals. Publications $d u$ Service géologique du Luxembourg 29, 259-263.

Lathuilière, B., Gaillard, C., Habrant, N., Bodeur, I., Boullier, A., Enay, R., Hanzo, M., Marchand, D., Thierry, J. \& Werner, W. 2005. Coral zonation of an Oxfordian reef tract in the northern French Jura. Facies 50, 545-559. DOI 10.1007/s10347-004-0035-4

LEINFELDER, R.R. 1993. A sequence stratigraphic approach of the Upper Jurassic mixed carbonate-siliclastic succession of the central Lusitanian Basin, Portugal. Profil 5, 119-140.

LEINFELDER, R.R. 2001. Jurassic reef ecosystems, 251-302. In Stanley JR., G.D. (ed.) The History and Sedimentology of Ancient Reef Systems. Kluwer Academic/Plenum Publishers, New York. DOI 10.1007/978-1-4615-1219-6 8

Leinfelder, R.R. \& Schmid, D.U. 2000. Mesozoic reefal thrombolites and other microbolites, 289-294. In RIDING, R.E. \& AwrAmiK, S.M. (eds) Microbial sediments. Springer, Berlin Heidelberg New York. DOI 10.1007/978-3-662-04036-2_31

Leinfelder, R.R., Nose, M., Schmid, D. \& Werner, W. 1993. Microbial crusts of the Late Jurassic: composition, palaeoecological significance and importance in reef construction. Facies 29, 195-229. DOI 10.1007/BF02536929
Leinfelder, R.R., Schmid, D.U., Nose, M. \& Werner, W. 2002. Jurassic reef patterns-The expression of a changing globe, 465-520. In Kiessling, W., Flügel, E. \& Golonka, J. (eds) Phanerozoic Reef Patterns. SEPM Special Publication 72. DOI 10.2110/pec.02.72.0465

Leinfelder, R.R., Werner, W., Nose, M., Schmid, D.U., Krautter, M., Laternser, R., Takacs, M. \& Hartmann, D. 1996. Paleoecology, growth parameters and dynamics of coral, sponge and microbolite reefs from the Late Jurassic, 227-248. In Reitner, J., Neuweiler, F. \& Gunkel, F. (eds) Global and Regional Controls on Biogenic Sedimentation, I. Reef Evolution. Research Reports Göttinger Arbeiten zur Geologie und Paläontologie Sb2.

LóPEz, J. 2011. Répartition spatiale et composition des faunes récifales le long d'une plate-forme carbonatée (Jura méridional français ; Jurassique supérieur). 49 pp. Master thesis, Université Claude Bernard Lyon 1, Lyon, France.

Mancini, E.A., Llins, J.C., Parcell, W.C., Aurell, M., Badenas, B., Leinfelder, R.R. \& Benson, D.J. 2004. Upper Jurassic thrombolite reservoir play, northeastern Gulf of Mexico. American Association of Petroleum Geologists Bulletin 88, 1573-1602. DOI 10.1306/06210404017

Martin-Garin, B. 2005. Climatic control of Oxfordian coral reef distribution in the Tethys Ocean. Including a comparative survey of Recent coral communities (Indian Ocean) and a new method of coral morphometrics based on fractal dimensions. 253 pp. Ph.D. thesis, Universität Bern und Universität Henri Poincaré Nancy I, Bern, Switzerland.

Martin-Garin, B., Lathuilière, B. \& Geister, J. 2012. The shifting biogeography of reef corals during the Oxfordian (Late Jurassic). A climatic control? Palaeogeography, Palaeoclimatology, Palaeoecology 365-366, 136-153.

DOI 10.1016/j.palaeo.2012.09.022

Martin-Garin, B., Lathuilière, B., Geister, J., Chellai, H. \& Huault, V. 2007. Geology, facies model and corals association of the Late Jurassic reef complex at Cape Ghir (Atlantic High Atlas, Morocco). Comptes Rendus Geoscience 339, 65-74. DOI 10.1016/j.crte.2006.10.007

Martin-Garin, B., Lathuilière, B., Geister, J. \& Ramseyer, K. 2010. Oxygen isotopes and climatic control of Oxfordian coral reefs (Jurassic, Tethys). Palaios 25, 721-729.

DOI 10.2110/palo.2010.p10-027r

Matyszkiewicz, J., Kochman, A. \& Duś, A. 2012. Influence of local sedimentary conditions on development of microbialites in the Oxfordian carbonate buildups from the southern part of the Kraków-Częstochowa Upland (South Poland). Sedimentary Geology 263, 109-132.

DOI 10.1016/j.sedgeo.2011.08.005

Matyszkiewicz, J., Krajewski, M. \& KęDZierski, J. 2006. Origin and evolution of an Upper Jurassic complex of carbonate buildups from Zegarowe Rocks (Kraków-Wieluń Upland, Poland). Facies 52, 249-263. DOI 10.1007/s10347-005-0038-9

Mazin, J.-M., Hantzpergue, P. \& Pouech, J. 2016. The dinosaur tracksite of Loulle (early Kimmeridgian; Jura, France). Geobios 49, 211-228. DOI 10.1016/j.geobios.2016.01.018

Mutti, M. \& Hallock, P. 2003. Carbonate systems along 
nutrient and temperature gradients: some sedimentological and geochemical constraints. International Journal of Earth Sciences 92, 465-475. DOI 10.1007/s00531-003-0350-y

Nose, M. 1995. Vergleichende Faziesanalyse und Palökologie korallenreicher Verflachungsabfolgen des iberischen Oberjura. Profil 8, 1-273.

Nose, M. \& Leinfelder, R.R. 1997. Upper Jurassic coral communities within siliciclastic settings (Lusitanian Basin, Portugal): implications for symbiotic and nutrient strategies. Proceeding $8^{\text {th }}$ International Coral Reef Symposium, June 1996, Panama City, 1755-1760.

Olivier, N. 2004. Microbialites dans les bioconstructions du Jurassique: morphologies, rôles édificateurs et significations paléoenvironnementales. 380 pp. Ph.D. thesis, Université Claude Bernard Lyon 1, Villeurbanne, France.

Olivier, N., Cariou, E. \& Hantzpergue, P. 2015. Evolution of a Late Oxfordian: early Kimmeridgian carbonate platform, French Jura Mountains. Swiss Journal of Geosciences 108, 273-288. DOI 10.1007/s00015-015-0189-9

Olivier, N., Lathuilière, B. \& Thiry-Bastien, P. 2006. Growth models of Bajocian coral-microbialite reefs of Chargey-lès-Port (eastern France): palaeoenvironmental interpretations. Facies 52, 113-127.

DOI 10.1007/s10347-005-0022-4

Olivier, N., Pittet, B. \& Mattioli, E. 2004b. Palaeoenvironmental control on sponge reefs and contemporaneous deep-shelf marl-limestone deposition (Late Oxfordian, southern Germany). Palaeogeography Palaeoclimatology Palaeoecology 212, 233-263.

DOI 10.1016/j.palaeo.2004.06.003

Olivier, N., Carpentier, C., Martin-Garin, B., Lathuilière, B., Gaillard, C., Ferry, S., Hantzpergue, P. \& Geister, J. 2004a. Coral-microbialite reefs in pure carbonate versus mixed carbonate-siliciclastic depositional environments: the example of the Pagny-sur-Meuse section (Upper Jurassic, northeastern France). Facies 50, 229-255.

DOI 10.1007/s10347-004-0018-5

Olivier, N., Colombier, C., Pittet, B. \& Lathuilière, B. 2011. Microbial carbonates and corals on the marginal French Jura platform (Late Oxfordian, Molinges section). Facies 57, 469-492. DOI 10.1007/s10347-010-0246-9

Olivier, N., Hantzpergue, P., Gaillard, C., Pittet, B., Leinfelder, R.R., Schmid, D.U. \& Werner, W. 2003. Microbialite morphology, structure and growth: a model of the Upper Jurassic reefs of the Chay Peninsula (western France). Palaeogeography, Palaeoclimatology, Palaeoecology 193, 383-404. DOI 10.1016/S0031-0182(03)00236-0

Olivier, N., Martin-Garin, B., Colombié, C., Cornée, J.J., Giraud, F., Schnyder, J., Kabbachi, B. \& Ezaidi, K. 2012. Ecological succession in an Upper Jurassic coral reef system (Izwarn section, High Atlas, Morocco). Geobios 45, 555-572. DOI 10.1016/j.geobios.2012.05.002

Olivier, N., Pittet, B., Gaillard, C. \& Hantzpergue, P. 2007. High-frequency palaeoenvironmental fluctuations recorded in Jurassic coral-and sponge-microbialite bioconstructions. Comptes Rendus Palevol 6, 21-36.

DOI 10.1016/j.crpv.2006.07.005
Olóriz, F., Reolid, M. \& Rodríguez-Tovar, F.J. 2012. Palaeogeography and relative sea-level history forcing eco-sedimentary contexts in Late Jurassic epicontinental shelves (Prebetic Zone, Betic Cordillera): an ecostratigraphic approach. Earth-Science Reviews 111, 154-178.

DOI 10.1016/j.earscirev.2011.11.004

Pawellek, T. \& Aigner, T. 2003. Apparently homogenous "reef"-limestones built by high-frequency cycles: Upper Jurassic, SW-Germany. Sedimentary Geology 160, 259-284. DOI 10.1016/S0037-0738(02)00379-2

Pittet, B. \& Strasser, A. 1998. Long-distance correlations by sequence stratigraphy and cyclostratigraphy; examples and implications (Oxfordian from the Swiss Jura, Spain, and Normandy). Geologische Rundschau 86, 852-874. DOI 10.1007/s005310050181

Pleș, G., Mircescu, C.V., Bucur, I.I. \& Săsăran, E. 2013. Encrusting micro-organisms and microbial structures in Upper Jurassic limestones from the Southern Carpathians (Romania). Facies 59, 19-48. DOI 10.1007/s10347-012-0325-1

Pratt, B.R. \& James, N.P. 1986. The St George Group (Lower Ordovician) of western Newfoundland: tidal flat island model for carbonate sedimentation in shallow epeiric seas. Sedimentology 33, 313-343.

DOI 10.1111/j.1365-3091.1986.tb00540.x

Purser, B.H. 1983. Sédimentation et diagenèse des carbonates néritiques récents. 389 pp. IFP Technip, Rueil Malmaison, Paris.

RANKEY, E.C. 2002. Spatial patterns of sediment accumulation on a Holocene tidal flat, Northwest Andros Island, Bahamas. Journal of Sedimentary Research 72, 591-601. DOI 10.1306/020702720591

Reolid, M., Gaillard, C. \& Lathuilière, B. 2007. Microfacies, microtaphonomic traits and foraminiferal assemblages from Upper Jurassic oolitic-coral limestones: stratigraphic fluctuations in a shallowing-upward sequence (French Jura, Middle Oxfordian). Facies 53, 553-574.

DOI 10.1007/s10347-007-0121-5

Reolid, M., Gaillard, C., Olóriz, F. \& Rodríguez-Tovar, F.J. 2005. Microbial encrustations from the Middle Oxfordianearliest Kimmeridgian lithofacies in the Prebetic Zone (Betic Cordillera, southern Spain): characterization, distribution and controlling factors. Facies 50, 529-543.

DOI 10.1007/s10347-004-0030-9

Reolid, M., Molina, J.M., Löser, H., Navarro, V. \& RuizOrtiz, P.A. 2009. Coral biostromes of the Middle Jurassic from the Subbetic (Betic Cordillera, southern Spain): facies, coral taxonomy, taphonomy, and palaeoecology. Facies 55, $575-593$. DOI 10.1007/s10347-009-0187-3

Ricci, C., Lathuilière, B. \& Rusciadelli, G. 2018b. Coral communities, zonation and paleoecology of an Upper Jurassic reef complex (Ellipsactinia Limestones, Central Apennines, Italy). Rivista Italiana di Paleontologia e Stratigrafia 124(3), 433-508.

Ricci, C., Rusciadelli, G., Della Porta, G., Lanfranchi, A., JADOUL, F. \& LATHUILIÈRE, B. 2018a. Sedimentary evolution 
of a coral-, microbialites-and debris-rich Upper Jurassic reef (upper Tithonian, eastern Sardinia, Italy). Sedimentary Geology 376, 113-35. DOI 10.1016/j.sedgeo.2018.07.010

Rusciadelli, G., Ricci, C., \& Lathuilière, B. 2011. The Ellipsactinia Limestones of the Marsica area (Central Apennines): a reference zonation model for Upper Jurassic Intra-Tethys reef complexes. Sedimentary Geology 233, 69-87.

DOI 10.1016/j.sedgeo.2010.10.011

San Miguel, G., Aurell, M. \& Bádenas, B. 2017. Occurrence of high-diversity metazoan-to microbial-dominated bioconstructions in a shallow Kimmeridgian carbonate ramp (Jabaloyas, Spain). Facies 63, 1-21. DOI 10.1007/s10347-017-0493-0

Schmid, D.U. 1996. Marine Mikrobolithe und Mikroinkrustierer aus dem Oberjura. Profil 9, 101-251.

Shiraishi, F. \& Kano, A. 2004. Composition and spatial distribution of microencrusters and microbial crusts in upper Jurassic-lowermost Cretaceous reef limestone (Torinosu Limestone, southwest Japan). Facies 502, 217-227. DOI 10.1007/s10347-004-0022-9

Sprachta, S., Camoin, G., Golubic, S. \& Campion, T.L. 2001. Microbialites in a modern lagoonal environment: nature and distribution, Tikehau atoll (French Polynesia). Palaeogeography Palaeoclimatology Palaeoecology 175, 103-124. DOI 10.1016/S0031-0182(01)00388-1

Stanley, G.D. 2003. The evolution of modern corals and their early history. Earth-Science Review 60, 195-225. DOI 10.1016/S0012-8252(02)00104-6

Stanley JR., G.D. \& Cairns, S.D. 1988. Constructional azooxanthellate coral communities: an overview with implications for the fossil record. Palaios 3, 233-242.

DOI $10.2307 / 3514534$
Strasser, A. 2007. Astronomical time scale for the Middle Oxfordian to Late Kimmeridgian in the Swiss and French Jura Mountains. Swiss Journal of Geosciences 100, 407-429. DOI 10.1007/s00015-007-1230-4

Strasser, A. \& Védrine, S. 2009. Controls on facies mosaics of carbonate platforms: a case study from the Oxfordian of the Swiss Jura, 199-213. In Swart, P.K., Eberli, G.P. \& McKenzie, J.A. (eds) Perspectives in Carbonate Geology: a Tribute to the Career of Robert Nathan Ginsburg. Special publication of the International Association of Sedimentologists 41. DOI 10.1002/9781444312065.ch13

ThiERry, J. et al. 2000. Early Kimmeridgian (146-144 Ma), Map 10, 85-97. In Dercourt, J., Gaetani, M., Vrielynck, B. et al. (eds) Atlas Peri-Tethys. Palaeogeographical Maps.

Tucker, M.E. \& Wright, V.P. 1990. Carbonate Sedimentology. 482 pp. Blackwell, Oxford. DOI 10.1002/9781444314175

Werner, W., Leinfelder, R.R., Fürsich, F.T. \& Krautter, M. 1994. Comparative palaeoecology of marly coralline sponge bearing reefal associations from the Kimmeridgian (Upper Jurassic) of Portugal and southwestern Germany. Courier Forschungsinstitut Senckenberg 172, 381-397.

Wright, V.P. \& Burgess, P.M. 2005. The carbonate factory continuum, facies mosaics and microfacies: an appraisal of some of the key concepts underpinning carbonate sedimentology. Facies 51, 19-25. DOI 10.1007/s10347-005-0049-6

Zamagni, J., Košrin, A. \& Mutti, M. 2009. The first microbialitecoral mounds in the Cenozoic (Uppermost Paleocene) from the Northern Tethys (Slovenia): Environmentally-triggered phase shifts preceding the PETM? Palaeogeography Palaeoclimatology Palaeoecology 274, 1-17.

DOI 10.1016/j.palaeo.2008.12.007 